\title{
The Accessibility Level of Cigudeg Village as Prospective Capital City of West Bogor Regency
}

\author{
Soma Trenggana
}

\author{
Geospatial Education and Training Center, Geospatial Information Agency, Jl. Raya Jakarta Bogor \\ KM 46 Cibinong, West Java Province, 16911, Indones ia
}

\begin{abstract}
This article contains a spatial review concerning the appointment of Cigudeg Village as a candidate of the capital city of Bogor Barat Regency. Bogor Barat Regency is one the regencies are being proposed to be a new regency in West Java Province. This research aimed to determine the feasibility of Cigudeg Village as the capital city candidate from the spatial accessibility point of view. The research begun by proposing other locations instead of Cigudeg Village as a comparison. The selection of village candidates was based on 3 scenarios: (1) all villages in Cigudeg District were deserved to be chosen as the capital city candidates; (2) all villages within the Bogor Barat Regency were deserved to be selected as the capital city candidates; (3) a centroid of Bogor Barat Regency was deserved to be included in the selection of the capital city of Bogor Barat Regency. The analysis of location-allocation weighted by the total population per district, was used to obtain the chosen village based on the above scenarios. The analysis resulted in three different chosen villages, that are Cigudeg (scenario 1), Leuwiliang (scenario 2) and Bayuresmi 2 (scenario 3). A comparative analysis then carried out to choose which village among those three that actually has a highest value of accessibility. Travel distance, travel time, and public transportation cost used a base of comparative analysis. The result of comparative analysis shows that Leuwiliang Village has the highest accessibility level, followed by Cigudeg and Bayuresmi 2 on the third place.
\end{abstract}

Keywords - Accessibility, Network Analyst, Cigudeg, Location-allocation, Google Maps, Grab.

\section{INTRODUCTION}

The choice of geographical location of the central government is very important for regional development. The central government is expected to be able to encourage regional development, encourage the spread of development and increase equity in development [14]. The district capital with its function as the center of government administration is also closely related as a service center for the community. The government sector here must be able to predominantly provide services to the community.

West Bogor Regency is a candidate for a new autonomous region that proposed by the government of West Java Province as a fraction of Bogor Regency. The expansion of West Bogor Regency is a priority for West Java Province considering that the Bogor Regency region is currently too broad with a number of districts around 40 districts. Assistant District Government of Bogor said that a region can do maximum service if it has a population of around 3 million people. At present Bogor Regency has 5.7 million inhabitants and this makes the range of control of public services and government supervision increasingly heavy [15].

According to information from the Cigudeg District office, West Bogor Regency candidate has determined Cigudeg Village of Cigudeg District as a candidate for the West Bogor Regency government center [6]. Determination of Cigudeg Village of as a candidate for the capital was a result of a study conducted by a team of regional planning consultant in 2008 [24].

In the selection of the location of the district capital, it is necessary to consider the technical aspects, strategic aspects and administrative aspects [19]. From this administrative aspect, one thing that needs to be considered is that the chosen capital or location should has the smallest total physical distance so that it is easily accessible from all regions for smooth operation in government services. Similar considerations were also applied by the provincial government of The Eastern Cape, South Africa in 1994 [28]. Two of the 6 considerations used by The Eastern Cape Provincial Government are (a) Centrality, which considers the geographical location of the capital in relation to the provincial population and (b) the accessibility of the provincial capital in regard to geographical accessibility which includes communication and infrastructure connections.

A research concerning the multi-factor consideration in selection of a capital for a country [18] even reported that the consideration of the central geographical location (centroid), that put the capital city in the middle of the 
administrative area has encouraged a number of countries to move the capital city of their country. Italy chose the city of Rome on the basis of consideration of its central position to connect south and north. The French capital, Paris, is also a central city that connects various cultural regions in the country, such as the Rhine culture, Frank culture, Roman culture, and so on. Kazakhstan moved its capital from Alma-Ata located in the southwest corner of the country to Akmola in the center. Nigeria moved its capital from Lagos in the western coastal region to downtown Abujia. Tanzania moved its capital from Dar es Salaam to Dodoma in the center of the country, which is almost the same distance from all administrative districts in the country. Belgrade, which was once the capital of Yugoslavia, and which is currently the capital of the Republic of Serbia, is located in the central position of the Balkan Peninsula. From the description above it appears that the aspect of geographical location in relation to accessibility and the balance of the distance between the capital and all administrative centers at a lower level are factors that must be considered in the selection of the capital city or government center. The choice of location based on the midpoint of the administrative (centroid) area basically also applies to the level of government below it, such as provinces, regencies and districts.

The Cigudeg District area, geographically, stretches from the centroid of West Bogor Regency to the north and west part of West Bogor Regency. Cigudeg Village itself is located in the western part of approximately $10 \mathrm{~km}$ from the centroid of West Bogor Regency. The location of Cigudeg Village, geographically, is suspected will create a wide disparity in distance between 14 districts within West Bogor Regency. To what extent this disparity occurs, it is necessary to conduct a spatial study related to travel distance, travel time and travel cost from each district to Cigudeg Village. In other word, it is necessary to evaluate spatially the accessibility level of Cigudeg Village.

There are several methods actually for measuring the accessibility level. However, for the case of measuring the accessibility level of Cigudeg Village, a comparative analysis by proposing other locations as a comparis on is considered the most suitable. This method is expected to be able to answer whether Cigudeg Village is feasible to be the capital of West Bogor Regency or otherwise another village. The use of comparative analysis by proposing other villages as a comparison is considered also to be at the right moment, since the determination letter of Cigudeg Village as the capital of West Bogor Regency has not been issued.

This study is intended to conduct spatial based analysis with the aim to determine the accessibility level of
Cigudeg Village as a candidate for government center of West Bogor Regency.

\section{EXPECTED BENEFITS}

The comparative analysis in this case could end up with the determination of Cigudeg Village or another village as a village that has the highest level of accessibility. The result will at least provide a second opinion for the West Java provincial government in determining the most suitable village to be designated as the capital of the West Bogor Regency.

The use of network analyst combined with the Google Maps and online transportation services in this study is expected to enable motivate those who take part in the geospatial field to further develop this combination of applications as part of the development of science and knowledge, in particular the development of network analyst.

As a person who is engaged in the field of education and training, the results of this study are expected to be able to encourage coaches involved in GIS training, particularly in the network analyst training to do the same research but in different cases. The series of studies in different cases is expected to enrich the experience and improve the knowledge and skills of the coaches that can finally be transferred to the participants.

This research is also expected to provide benefits to the communities in saving travel time and costs, especially for people who have high mobility, and the business actors in goods and services distribution.

\section{LITERATURE REVIEW}

\subsection{Accessibility and accessibility parameters}

The concept of accessibility has been used in a number of scientific fields over the past few decades such as transportation planning, urban planning and geography, and plays an important role in policy making. Accessibility is generally used to refer to efforts, means, or modes, by which a goal can be achieved [4]. In general accessibility is defined as the ease (or difficulty) of services that can be achieved from a location [11]. Others define it as the ability to reach a place in relation to another place [25]. In this context, accessibility refers to the ease of achieving goals. The closer the origin and destination to the transportation system the higher the level of accessibility. The more variations in modes of transportation to travel from the place of orig in to a particular destination, the better the accessibility. The less time and money spent on the trip, the more that can be achieved in a particular budget, the greater the accessibility [17]. Furthermore [25] said that accessibility determines equal access and opportunities, and 
accessibility related to geography is an important element in the mobility of people, goods, or information.

The component of accessibility can be identified from various aspects and practical values which are theoretically important in measuring accessibility [12]. These aspects are land use, transportation, time and individuals. Two main components of accessibility in transportation and geography are location and distance [25]. A more detailed explanation states [16], that accessibility in transportation systems includes components of distance, time taken and costs to reach each destination with different modes of transportation, while accessibility of location usually consists of two elements: (a) transportation elements (resistance or impedance) and (b) elements of activity (motivation or attraction or utility). Measurement of accessibility generally use impedance, time, or public transportation costs, and urban spatial distributions to produce numerical accessibility indexes for each location in the study area [16].

\subsection{Travel distance parameter}

The distance between two or more locations in the transportation systemand geography can be interpreted as spatial distance. In general there are 3 methods of calculating spatial distance, that are: (a) Euclidean distances; (b) Vector-based road network and (c) Rasterbased cost-weighted distances [27]. The distance of actual vector-based road networks [8] is considered as the best alternative and more in-line with human perceptions of access to open space. Actual travel distance based on road networks basically measures the distance between the parcel and the closest open space that is in demand [27]. Regarding to the measurement of spatial distance, geographic information systems (GIS) are the only technology that capable of conducting the spatial distance analysis. The Esri Network Analyst tools have been widely used by researchers or practitioners in vectorbased road-network actual calculation. [10]. [35], [37], [1], [3], and [2] are 5 researchers of many researchers who have used Esri Network Analyst tools in their researchs.

Besides ESRI Network Analyst, several web/ online GIS applications such as Google Maps, Mapquest, Bing and Rand McNally also offer accurate driving directions in almost all locations in the world [8]. This web / online GIS application is even able to eliminate the cost of road network-based distance analysis caused by purchasing a software and procurement history of travel data as happens when using the Desktop Esri Network Analyst [8]. A comparative test on the distance between Google Maps and Network analyst showed that results were not significantly different [36].

\subsection{Travel time parameter}

Associated with the calculation of travel time, in the 1970s research mostly focused on understanding physical distance between points [22]. The focus on time perception begins later with the understanding that travel time turns out to be far more important than actual physical distance [23]. Furthermore, insofar as travel time by car and transit varies by time of day, this means accessibility also varies in and across days [20]. Travel time is broadly defined as the time necessary to traverse a route between any two points of interest. Travel time can be directly measured by traversing the route(s) that connects any two or more points of interest. Travel time is composed of running time, or time in which the mode of transport is in motion, and stopped delay time, or time in which the mode of transport is stopped (or moving sufficiently slow as to be stopped) [31]. The use of ArcGIS 10 software has been carried out in order to conduct travel time modeling through an approach: (a). Travel time by private car; (b) Travel time by public transportation; and (c) Door-to-door approach. Their modeling concluded that travel time calculations require a software with capabilities more than standard GIS software [26].

The estimation of actual travel time is also offered by Web- GIS based applications, such as Google Maps [8]. A research aimed to get an estimation of the O-D trip time matrix with the Google Maps approach, found at least 4 advantages of the Google Maps API compared to the ArcGIS Network Analyst approach. These advantages are: (a) no need to prepare a network datas et; (b) use more updated road data; (c) take into account road congestion and (d) consider the difference between rush hour and non-busy hours [34]. The use of Google Maps based data for analysis of travel time is also carried out in the city of Kaunas [9]. In this analysis they concluded that Google Maps provides a variety of data about car travel times that can be accessed through the Google Matrix Distance. With these data they were able to make an average travel time matrix that can be used as a skim matrix to validate the macro model of the city of Kaunas.

\subsection{Public transportation cost parameter}

Accessibility is basically the cost of travel between the place of origin and destination [11]. A research about applying time-varying travel-time costs for emergency response vehicle routing in Davis County, Utah, concluded that the latest technological developments with electronic tariff payment systems and the use of GPS devices created favorable conditions for implementing a distance-based tariff structure [35]. This model was explicitly able to track passenger routes so that allowing to accurately calculate the distance-based rates. The distance-based tariff calculation system is now the basis 
for determining travel fares or fees from online-based public transportation services such as Grab, Go-jek, and Uber [32].

Online transportation is one of the latest service innovations in m-commerce. Online transportation services or travel sharing are individual transportation services where customers can book trips (cars, motorbikes, etc.) through cellular applications and drivers can respond to orders through applications [33]. This service provides several benefits such as the driver and the customer can find out the location of each other accurately, customers can see driver and vehicle information, and customers can easily find transportation to go to another place (time efficiency). The transportation services combined with the sophistication of internet technology made it easier for people to place an order, know the rate of transportation costs, location of destination and driver's identity [5]. This benefit makes travel sharing increasingly popular among urban communities.

Online transportation services or sharing trips are now a common means for people to fulfill their travel needs [29]., The popular online transportation services for Indonesia currently are Go-Jek and Grab which hold the largest market share and compete each other. The popularity of Grab and Go-Jek as an online means of transportation implicitly shows that the rates offered by these two transportation services can be considered as representing the rates of travel by public transportation. On the basis of the above arguments, the accessibility measurement of prospective capital of West Bogor Regency on the parameter of public transportation cost, will likely use the estimated travel fares provided by Grab application.

\subsection{Network Analyst}

The Network Analyst application is GIS software that utilizes topology point and line features that are packaged in network data sets. Network analyst has 6 functions of analysis, namely: (a) New Route to calculate the best travel route according to distance and travel time from the point of origin to the destination point; (b) New Service Area to calculate the service range of service centers based on distance or travel time; (c) New Closest Facility to calculate the nearest service center from the incident; (d) New O - D matrix to calculate distance or travel time from the origin to various destination points; (e) New Vehicle Routing Problem to calculate the best travel routes in serving a number of consumers; (f) New Location-Allocation to select service centers from a number of proposed service centers [10].

\subsection{Research Approach}

RESEARCH METHODS

This study uses a spatial approach by utilizing geospatial data and Geographic Information System (SIG) technology - Network Analyst, assisted with Google Maps application, and the online based transportation service application (Grab).

\subsection{Research Sites}

The research area is the administrative area of the West Bogor Regency candidate with the coverage area as shown in Fig. 1. The prospective West Bogor Regency is geographically located between $106^{\circ} 24^{\prime} 0$ "E to $106^{\circ} 46^{\prime} 0^{\prime \prime} \mathrm{E}$ and between $6^{\circ} 18^{\prime} 0^{\prime \prime} \mathrm{S}$ to $6^{\circ} 46^{\prime} 0^{\prime \prime} \mathrm{S}$. This prospective regency is bordered by Bogor City and Bogor Regency on the East side, Sukabumi Regency on the South side, Lebak Regency on the West side, and Tanggerang Regency and Tangerang Selatan City on the North side. It has an area of approximately 131,761.94 ha with a population in 2017 of around 1,514,577 people [7].

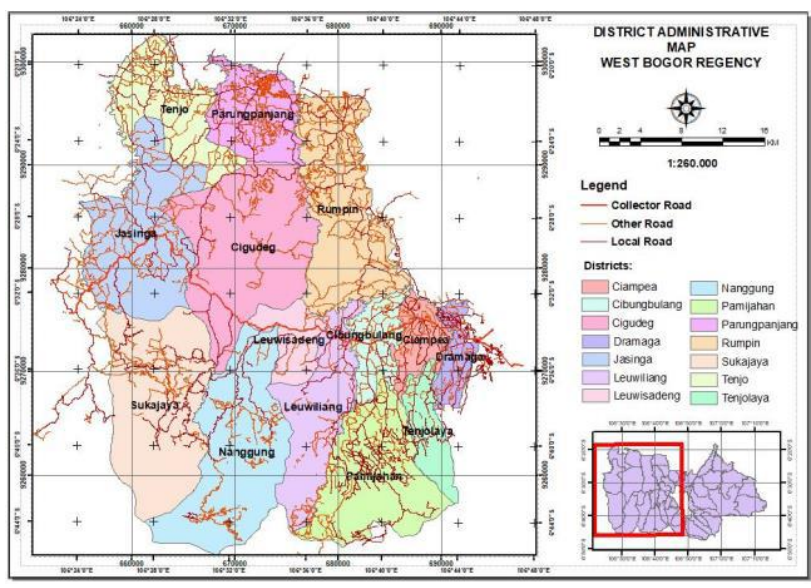

Fig 1. Map of prospective West Bogor Regency

The West Bogor Regency candidate is planned to consist of 14 districts and 166 villages. The 14 districts are Leuwiliang, Ciampea, Cibungbulang, Pamijahan, Rumpin, Jasinga, Parung Panjang, Nanggung, Cigudeg, Tenjo, Dramaga, Sukajaya, Leuwisadeng and Tenjolaya Districts. Cigudeg district itself as a candidate for the central government consists of 15 villages, namely: Argapura, Bangunjaya, Banyuasih, Banyuresmi, Banyuwangi, Batujajar, Cintamanik, Mekarjaya, Rengasjajar, Sukamaju, Sukaraksa, Tegarlega, Wargajaya and Cigudeg villages [6]. All villages and districts are connected to one another through road infrastructure which is dominated by other roads and local roads. The only collector road that crosses the West Bogor Regency candidate is a road that connects Bogor City with Rangkasbitung, Lebak Regency. Henceforth, the prospective West Bogor Regency will be referred to as West Bogor Regency. 


\subsection{Analysis Method}

This research was conducted in stages using 3 (three) applications, that were Network Analyst, Google Maps and Grab. The first stage was to determine the selected village, the second stage was to calculate the distance to the selected village. The third stage estimated the travel time to the selected village, the fourth stage estimated the cost of public transportation to the selected village, and the final stage determined the level of accessibility among the selected villages.

\subsubsection{Determination of Village candidates for the capital city.}

Determination of the village candidates for West Bogor Regency capital city here was done by using the analysis function of new location-allocation. In this analysis of the new location-allocation, the centroid of the village acts as a service center (facility) or as the capital of regency, while the centroid of the district acts as a party that requires service (demand). In accordance with the purpose of the study, which is conducting a comparative review, the analysis of the new location-allocation determines the village capital candidates based on 3 scenarios, namely: (1) Cigudeg District as a candidate for the West Bogor Regency capital, and all villages in the Cigudeg District have the opportunity to become the location of prospective capital cities; (2) All villages within the West Bogor Regency administrative area basically have the opportunity to be chosen as the location of prospective capital cities; (3) The geographical centroid location of the West Bogor Regency has the opportunity to be chosen as the location of the prospective capital city.

The first scenario is basically to ensure that spatially the Cigudeg Village is indeed chosen among 15 villages in the Cigudeg District area. Scenarios 2 and 3 are intended to get selected villages that will be used as a comparison for the first scenario.

The data used were the Indonesian topographic digital map scale of 1:25.000 downloaded from http://tanahair.indonesia.go.id/portal-web/download/per region [13]. The layers used as analysis material were: (a) Road layer, (b) Administrative layer, and (c) DEM (digital elevation model). While data on population per district was downloaded from https://bogorkab.bps.go.id/statictable / 2017 / [7].

The following was the sequence of analysis stages for the determination of village candidates for the capital city of West Bogor Regency:

(a) Creating the village centroid layer, the district centroid layer and the West Bogor Regency centroid layer. For the district centroid layer, the attribute table was completed with data of the population per district. Data of the population per district was used as a weight in the new location-allocation analysis. Fig 2. below explains the flow of making a centroid layer.

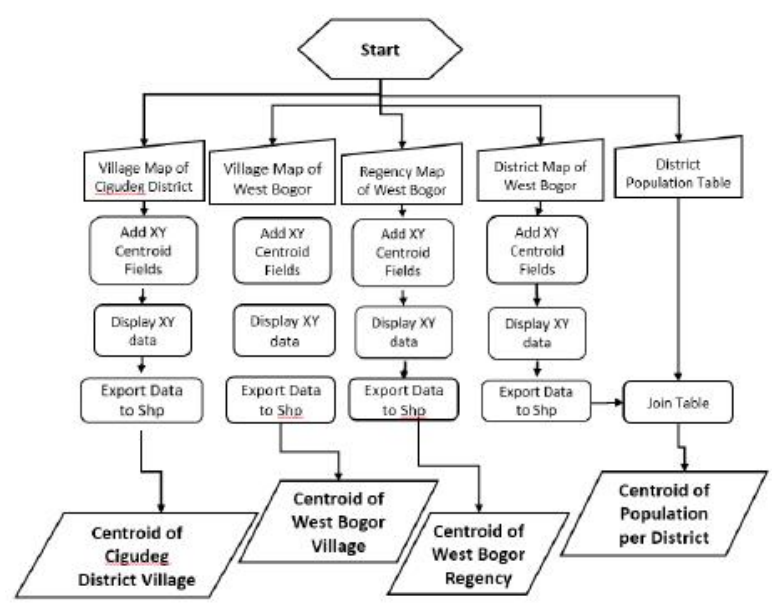

Fig 2. Flow map for making a centroid (midpoint)

(b) Setting up a network dataset. Since network analyst only works on network data, then compiling network data sets is very necessary. Setting up a network dataset conducted in a Personal Geodatabase of ArcGIS 10.2.1 using Road layer and Turn layer as input. Fig. 3. below is the flow of setting up a network dataset.

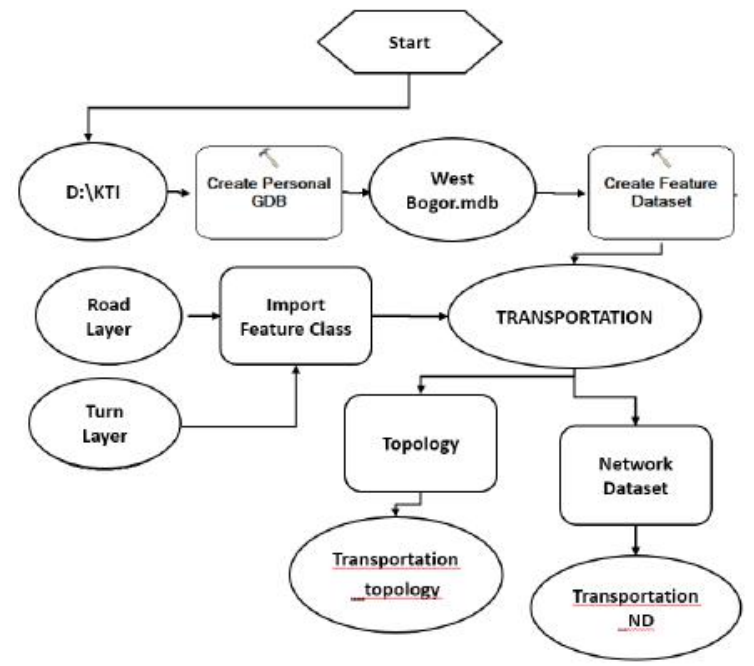

Fig. 3. Flow of setting up network datasets

(c) New location-allocation analys is to determine selected villages. This analysis used impedance settings: Distance (meters), Travel from: Demand to Facility; U-turn: allowed; Output type: straight line; Restriction: Turns; Problem Type: Maximum Attendance (maximum visit); Facility to Choose: 1; Impedance Cutoff: 40000 meters; and impediment transformation: Linear. Fig.4. below explains the analys is stage of New location-allocation. 


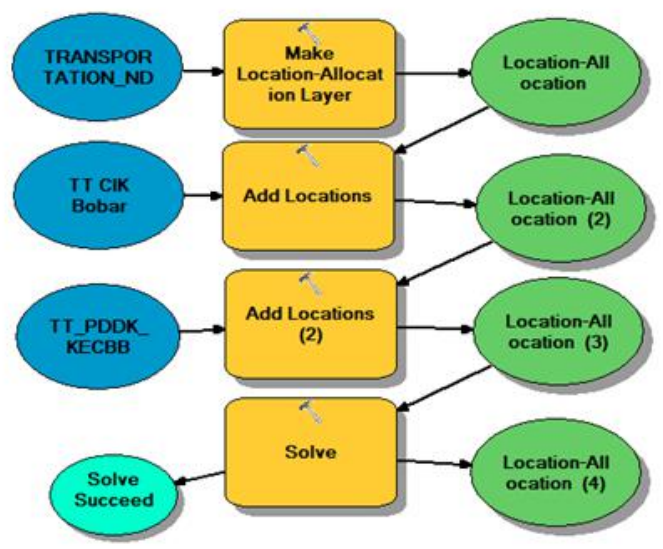

Fig.4. Model builder of analysis function new location-allocation

\subsubsection{Calculation of the distance to the selected} villages.

Calculation of the distance to the selected village was carried out using the analysis function of the New closest facilities. This function of analysis was aimed to obtain the shortest travel route between the districts to the selected village. This analysis will produce a map that describes the road segments that are passed and the mileage tables from 14 districts to 3 selected villages. Fig. 5. explains the flow of analysis of the New closest facility.

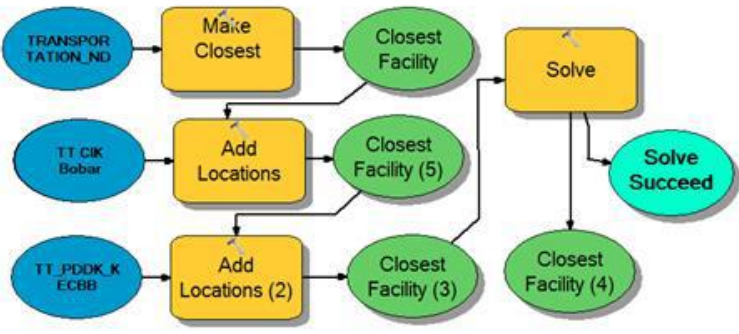

Fig.5. Model builder of analysis function for new closest facility.

4.3.3 Estimation of travel time to the selected villages The estimation of travel time from each district to the selected villages was carried out with the help of the Google Maps application. Google Maps was used to calculate the travel time of travel routes from the centroid of each district to the three selected villages resulted from of the New closest facility analysis.

The following were the stages of work to get estimated travel time from each district to the 3 selected villages:

(a) Inserting 17 centroid coordinates into the Google Maps application manually. 3 centroid points are the selected village centroids. The other 14 centroid points are the midpoint of the district. (b) Recording of travel time from 14 districts to 3 selected villages through the Google Maps application. Recording of travel time carried out for 7 days during rush hour (06.00 - 09.00 AM and 04.00 - 07.00 PM) and normal hour. Fig.6. below describes the stage of entering the centroid coordinates of 14 districts and 3 selected villages into the Google Maps application and recording travel time data and public transportation costs

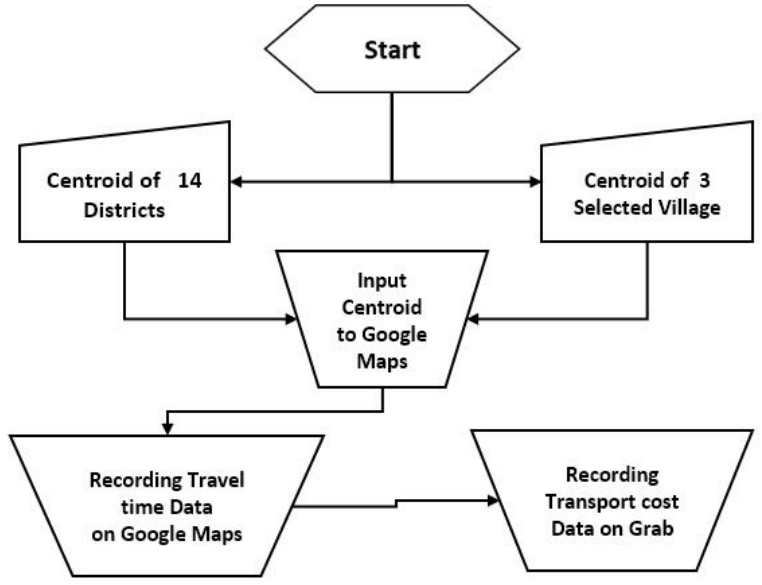

Fig. 6. Flow of recording travel time estimation and public transportation cost from 14 districts to 3 selected villages

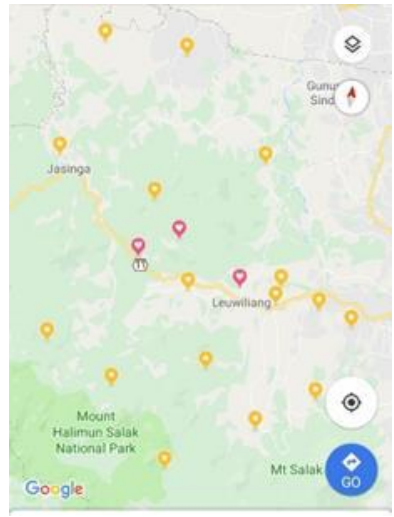

Fig 6. 17 Centroid coordinates on Google Maps application

\subsubsection{Estimation of public transportation cost to the selected villages.}

Calculation of public transportation cost was done with the help of the Grab application. Grab application in this case was used to calculate the cost of public transportation from each district centroid to the three selected villages vice versa. Recording of public transportation cost was carried out for 7 days during peak (rush) hour (06.00 - 09.00 AM and 04.00 - 07.00 PM) and normal hour. Recording of public transportation cost was carried out at the same time as recording travel time. The analysis of travel time and the cost of public transportation is intended to get the average travel time 
estimation and transportation cost from each dis trict to the three selected villages. Calculations were carried out

$$
\begin{aligned}
& \bar{x}=\frac{x_{1}+x_{2}+x_{3}+\ldots \ldots+x_{n}}{n} \\
& \bar{x}=\frac{1}{n} \sum_{i=1}^{n} x_{1}
\end{aligned}
$$

using a simple statistical formula.

Where:

$\mathrm{X}=$ average value

$\mathrm{Xn}=$ recording data

$\mathrm{n}$ = number of samples

\subsubsection{Accessibility analys is}

Accessibility analysis is aimed to determine which village among these 3 selected villages that has the highest level of accessibility. The simple statistical comparative analysis was adopted to compare the accessibility levels to the 3 chosen villages. The parameters used as a comparison are (1) distance, (2) travel time and (3) public transportation costs. Determination of the accessibility level refers to the basic principal of accessibility, introduced by Liu and Zhu, (2004) who said that the closer the origin and destination to the transportation system the higher the level of accessibility. The less time and money spent on the trip, the greater the accessibility. Determination also refer to Ilhami (1990) in Mahathir (2017) who stated that the capital or selected location should has the smallest total physical distance so that it is easily accessible from all regions for smooth operation in government services

\section{RESULTS}

\subsection{Scenario 1}

In the first scenario, where 15 villages in the Cigudeg District are involved as candidates, the analysis of the new location-allocation defines Cigudeg Village as a chosen candidate (Fig. 7) With the choice of Cigudeg Village as the capital city, as it shown in Table 1. the local government must provide public services with a service distance of up to $29,03 \mathrm{~km}$. The statistical calculation as shown on the right side of Table 1. shows that the range of local government services reached a total of $296,79 \mathrm{~km}$ with an average service range of $21,2 \mathrm{~km}$. The minimum service range is experienced by Leuwisadeng District with a distance of only $8,14 \mathrm{~km}$.

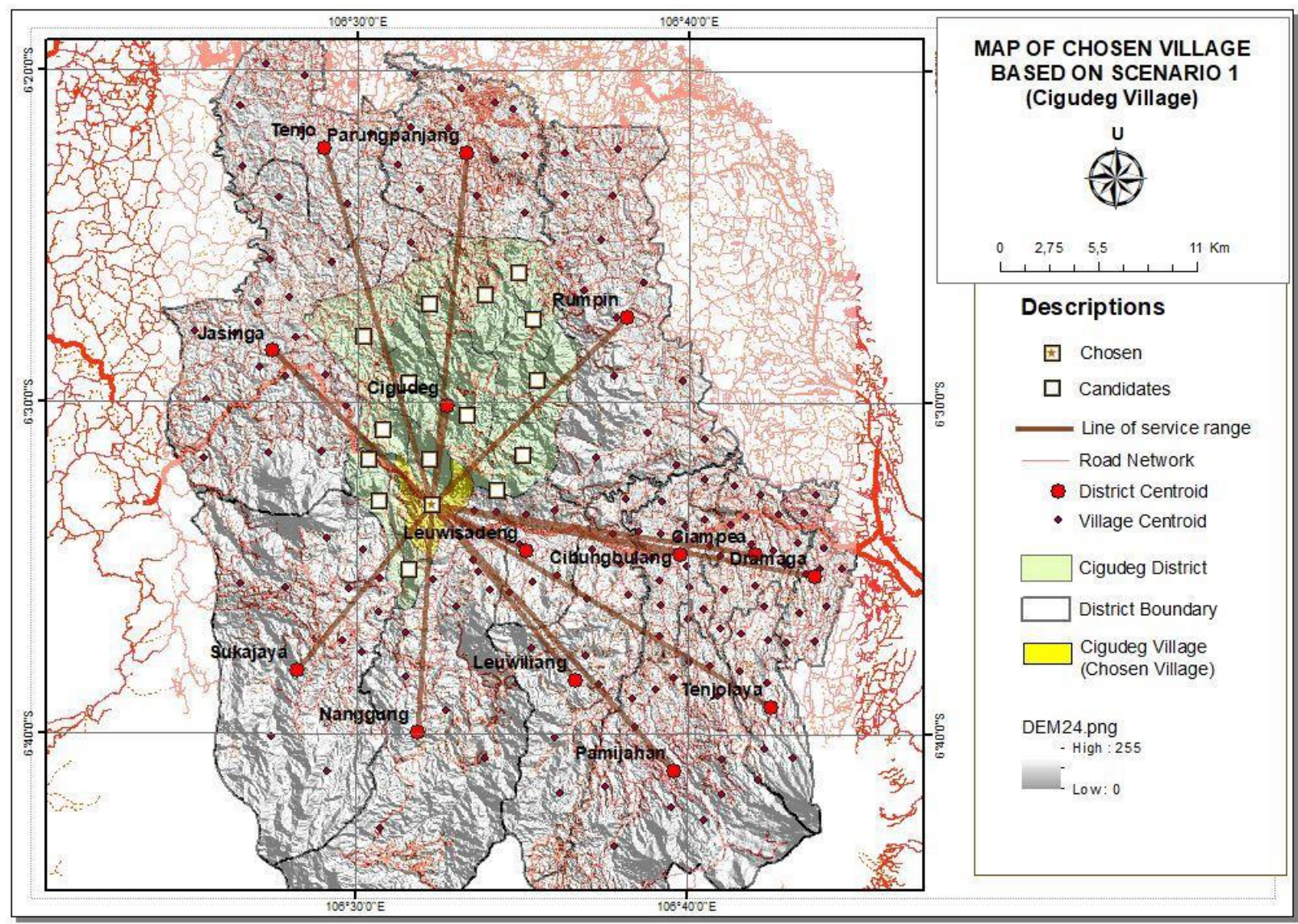

Fig. 7. Results of new location-allocation analysis based on scenario 1 
Table.1. Range of Cigudeg Village Services as Capital City Candidates

\begin{tabular}{|c|c|c|c|c|c|}
\hline \multicolumn{5}{|c|}{ Location_Allocation_Desa__igudeg } & \\
\hline & FID & Weight & District - Village & Distance from Village & \\
\hline & 0 & 0,44 & Ciampea - Cigudeg & $22,5 \mathrm{~km}$ & Field \\
\hline & 1 & 0,59 & Cibungbulang - Cigudeg & $16,21 \mathrm{~km}$ & \multirow{2}{*}{ Distance from Vilage } \\
\hline & 2 & 0,72 & Cigudeg - Cigndeg & $11,15 \mathrm{~km}$ & \\
\hline & 3 & 0,28 & Dramaga - Cigudeg & $28,83 \mathrm{~km}$ & Statistics: \\
\hline & 4 & 0,62 & Jasinga - Cigudeg & $15,21 \mathrm{~km}$ & \multirow{10}{*}{$\begin{array}{ll}\text { Count } \quad 14 \\
\text { Mnimum: } 8,14 \\
\text { Maximumn } 29,030001 \\
\text { Sum: } 296,799999 \\
\text { Mean: } 21,2 \\
\text { Standard Devation: } 6,783617 \\
\text { Nuls: } \quad 0\end{array}$} \\
\hline & 5 & 0,38 & Leuwiliang - Cigudeg & $24,68 \mathrm{~km}$ & \\
\hline & 6 & 0,8 & Leuwisadeng - Cigudeg & $8,14 \mathrm{~km}$ & \\
\hline & 7 & 0,59 & Nangrnung - Cigudeg & $16,46 \mathrm{~km}$ & \\
\hline & 8 & 0.29 & Pamijahan - Cigndeg & $28,59 \mathrm{~km}$ & \\
\hline & 9 & 0,32 & Parungpanjang - Cigudeg & $27,14 \mathrm{~km}$ & \\
\hline & 10 & 0,37 & Rumpin-Cigudeg & $25,26 \mathrm{~km}$ & \\
\hline & 11 & 0,58 & Sukajaya - Cigudeg & $16,85 \mathrm{~km}$ & \\
\hline & 12 & 0,33 & Tenjo - Cigudeg & $26,75 \mathrm{~km}$ & \\
\hline & 13 & 0,27 & Tenjolaya - Cigudeg & $29,03 \mathrm{~km}$ & \\
\hline
\end{tabular}

travel routes were obtained, that are the route from 14 districts to Cigudeg Village. The detailed results of the new closest facility can be seen visually in Fig. 8, where there are 14 blue lines that describe in detail the road segments passed by each route. Based on the analysis of the new closest facility, the 14 travel routes from each district to Cigudeg Village produce route distance as shown in Table 3.

\subsubsection{Mileage}

From the new closet facility analysis by determining the village of Cigudeg as the chosen village, the 14 shortest

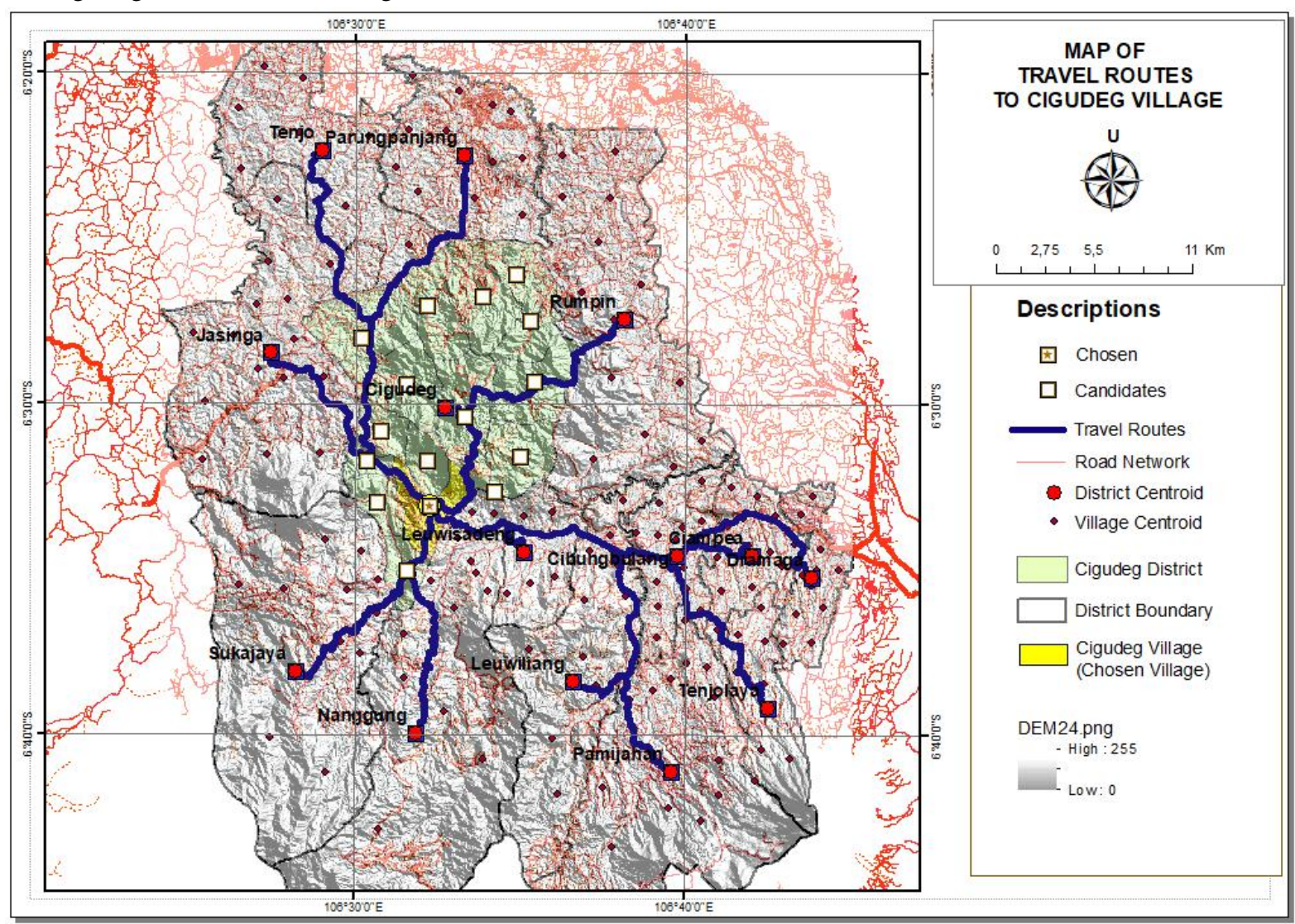

Fig. 8. Results ofnew closest facility analysis based on scenario 1

Table 2. Average Mileage of Each District Towards Cigudeg Village

\begin{tabular}{|c|c|c|c|}
\hline \multicolumn{3}{|c|}{ Travel Routes to Cigudeg Village } & \multirow{2}{*}{ Statistics of Rute_ke_Desa_Cigudeg } \\
\hline FID & \begin{tabular}{|l|} 
Travel Route \\
\end{tabular} & Travel Distance & \\
\hline & Leuwisadeng - Cigudeg & $8,14 \mathrm{~km}$ & \multirow{2}{*}{ Field } \\
\hline 2 & Cigudeg - Cigudeg & $11,15 \mathrm{~km}$ & \\
\hline 4 & Jasinga - Cigudeg & $15,21 \mathrm{~km}$ & Travel Distance \\
\hline & Cibungbulang - Cigudeg & $16,21 \mathrm{~km}$ & \multirow{2}{*}{ Statistics: } \\
\hline 7 & Nanggung - Cigudeg & $16,46 \mathrm{~km}$ & \\
\hline 11 & Sukajaya-Cigudeg & $16,85 \mathrm{~km}$ & \multirow{9}{*}{$\begin{array}{ll}\text { Count: } & 14 \\
\text { Minimum: } & 8,14 \\
\text { Maximum: } 29,030001 \\
\text { Sum: } 296,799999 \\
\text { Mean: } 21,2 \\
\text { Standard Deviation: } 6,783617 \\
\text { Nulls: } \quad 0\end{array}$} \\
\hline 0 & Ciampea - Cigudeg & $22,5 \mathrm{~km}$ & \\
\hline 5 & Leuwiliang - Cigudeg & $24,68 \mathrm{~km}$ & \\
\hline 10 & Rumpin - Cigudeg & $25.26 \mathrm{~km}$ & \\
\hline 12 & Tenjo - Cigudeg & $26,75 \mathrm{~km}$ & \\
\hline 9 & Parungpanjang - Cigudeg & $27,14 \mathrm{~km}$ & \\
\hline 8 & Pamijahan - Cigudeg & $28,59 \mathrm{~km}$ & \\
\hline 3 & Dramaga - Cigudeg & $28,83 \mathrm{~km}$ & \\
\hline 13 & Tenjolaya - Cigudeg & $29,03 \mathrm{~km}$ & \\
\hline
\end{tabular}

The statistical calculation on the right side of Table 2 . shows that the longest route is $29,03 \mathrm{~km}$, that is the Tenjolaya District - Cigudeg Village route. The shortest route to Cigudeg Village is experienced by Leuwisadeng District with a distance of $8,14 \mathrm{~km}$. The total number of routes from 14 districts to Cigudeg Village reaches $296.79 \mathrm{~km}$ or an average of $21,2 \mathrm{~km}$.

5.1.2 Travel time estimation

From the results of observations for 7 days on the travel time estimation from each district to Cigudeg Village, it shows that each route requires a daily average travel time as described in Table 3. 
The Table 3. describes that difference in travel time during rush hour with normal hours for each route ranges from 1 to -4 minutes, with an average for all routes around $-1,52$ minutes. This this actually indicates that the speed of vehicles during the normal hour tends to be slower.

Table 3. The Average Travel Time From 14 Districts to Cigudeg Village

\begin{tabular}{|c|c|c|c|c|c|}
\hline \multirow{2}{*}{ No } & \multirow{2}{*}{ District } & \multicolumn{4}{|c|}{ Average Travel Time (Minutes) } \\
\hline & & Rush Hour (S) & Normal hours (TS) & Difference & Daily \\
\hline 1 & Dramaga & 71,57 & 72,86 & $-1,29$ & 72,21 \\
\hline 2 & Cibungbulang & 39,00 & 41,43 & $-2,43$ & 40,21 \\
\hline 3 & Ciampea & 52,14 & 55,00 & $-2,86$ & 53,57 \\
\hline 4 & Leuwiliang & 50,43 & 53,00 & $-2,57$ & 51,71 \\
\hline 5 & Lewisadeng & 27,14 & 26,14 & 1,00 & 26,64 \\
\hline 6 & Pamijahan & 67,43 & 69,29 & $-1,86$ & 68,36 \\
\hline 7 & Rumpin & 66,71 & 69,00 & $-2,29$ & 67,86 \\
\hline 8 & Jasinga & 28,00 & 29,14 & $-1,14$ & 28,57 \\
\hline 9 & Parung Panjang & 53,14 & 55,57 & $-2,43$ & 54,36 \\
\hline 10 & Nanggung & 58,14 & 58,14 & 0,00 & 58,14 \\
\hline 11 & Cigudeg & 29,29 & 28,57 & 0,71 & 28,93 \\
\hline 12 & Tenjo & 71,43 & 72,57 & $-1,14$ & 72,00 \\
\hline 13 & Sukajaya & 62,29 & 63,14 & $-0,86$ & 62,71 \\
\hline 14 & Tenjolaya & 71,86 & 76,00 & $-4,14$ & 73,93 \\
\hline & Total & 748,57 & 769,86 & $-21,29$ & 759,21 \\
\hline & Average & 53,47 & 54,99 & $-1,52$ & 54,23 \\
\hline
\end{tabular}

For this small difference, the rush hour and normal hour travel times can be considered to be no difference, and the average daily travel time can be used as a benchmark for travel time estimation. The total amount of daily travel time to Cigudeg village reaches 759,21 minutes or an average of 54,2 minutes.

\subsubsection{Public transportation cost estimation.}

Based on observations for 7 days on public transportation costs using 2-wheeled and 4-wheeled vehicles, passengers who travel from the district to Cigudeg Village vice versa, must issue transportation costs as shown in Tables 4 and 5 .

Table 4. The Average 2 Wheeled Transport Costs from each District to Cigudeg Village Vice Versa

\begin{tabular}{|r|l|c|c|c|c|}
\hline \multirow{2}{*}{ No } & \multirow{2}{*}{ District } & \multicolumn{4}{|c|}{ Average GrabBike Transportation Fee (IDR x1000) } \\
\cline { 3 - 6 } & & Rush Hour (S) & Normal hours (TS) & Difference & Daily \\
\hline 1 & Dramaga & 90,71 & 85,00 & 5,71 & 87,86 \\
\hline 2 & Cibungbulang & 46,14 & 42,57 & 3,57 & 44,36 \\
\hline 3 & Ciampea & 68,00 & 63,43 & 4,57 & 65,71 \\
\hline 4 & Leuwiliang & 58,43 & 58,29 & 0,14 & 58,36 \\
\hline 5 & Lewisadeng & 23,43 & 23,43 & 0,00 & 23,43 \\
\hline 6 & Pamijahan & 92,29 & 86,43 & 5,86 & 89,36 \\
\hline 7 & Rumpin & 93,86 & 87,00 & 6,86 & 90,43 \\
\hline 8 & Jasinga & 36,14 & 35,86 & 0,29 & 36,00 \\
\hline 9 & Parung Panjang & 86,29 & 80,29 & 6,00 & 83,29 \\
\hline 10 & Nanggung & 51,43 & 51,14 & 0,29 & 51,29 \\
\hline 11 & Cigudeg & 22,14 & 20,71 & 1,43 & 21,43 \\
\hline 12 & Tenjo & 100,43 & 94,43 & 6,00 & 97,43 \\
\hline 13 & Sukajaya & 55,14 & 53,57 & 1,57 & 54,36 \\
\hline 14 & Tenjolaya & 100,00 & 93,86 & 6,14 & 96,93 \\
\hline & Total & 924,43 & 876,00 & 48,43 & 900,21 \\
\hline \multicolumn{2}{r|}{ Average } & 66,03 & 62,57 & & 64,30 \\
\hline
\end{tabular}

Table 5. The Average 4 Wheeled Transport Costs from each District to Cigudeg Village Vice Versa.

\begin{tabular}{|c|c|c|c|c|c|}
\hline \multirow{2}{*}{ No } & \multirow{2}{*}{ District } & \multicolumn{4}{|c|}{ Average GrabCar Transportation Fee (IDR x1000) } \\
\hline & & Rush Hour (S) & Normal hours (TS) & Difference & Daily \\
\hline 1 & Dramaga & 129,43 & 124,86 & 4,57 & 127,14 \\
\hline 2 & Cibungbulang & 82,43 & 75,71 & 6,71 & 79,07 \\
\hline 3 & Ciampea & 105,43 & 101,86 & 3,57 & 103,64 \\
\hline 4 & Leuwiliang & 89,00 & 85,57 & 3,43 & 87,29 \\
\hline 5 & Lewisadeng & 43,14 & 42,00 & 1,14 & 42,57 \\
\hline 6 & Pamijahan & 128,43 & 122,86 & 5,57 & 125,64 \\
\hline 7 & Rumpin & 132,71 & 131,43 & 1,29 & 132,07 \\
\hline 8 & Jasinga & 59,14 & 57,00 & 2,14 & 58,07 \\
\hline 9 & Parung Panjang & 121,86 & 110,29 & 11,57 & 116,07 \\
\hline 10 & Nanggung & 77,43 & 75,43 & 2,00 & 76,43 \\
\hline 11 & Cigudeg & 43,86 & 43,14 & 0,71 & 43,50 \\
\hline 12 & Tenjo & 124,00 & 123,00 & 1,00 & 123,50 \\
\hline 13 & Sukajaya & 78,43 & 73,57 & 4,86 & 76,00 \\
\hline 14 & Tenjolaya & 136,29 & 131,86 & 4,43 & 134,07 \\
\hline & Total & 1351,57 & 1298,57 & 53,00 & 1325,07 \\
\hline & Average & 96,54 & 92,76 & 3,79 & 94,65 \\
\hline
\end{tabular}

From the two tables above, it can be seen that there are differences in transportation costs during rush hour and normal hours. This difference has become the provision of Grab as the manager of online transportation where there is a difference in tariffs of IDR 5000 between rush hour and normal hours which apply to both GrabBike and GrabCar. If the transportation cost of each of these subdistricts are summed and then the average value is taken, the transportation cost to and from Cigudeg Village is around of IDR 64.300 for 2 wheeled vehicle and IDR. 94.650 for 4 wheeled vehicle.

\subsection{Scenario 2}

The new location-allocation analys is in scenario 2, where 166 villages plus the centroid of The West Bogor Regency were included as candidates, determines that the village of Leuwiliang deserved to be selected as a village of capital city of The West Bogor Regency. The location of the Leuwiliang Village can be seen in Fig. 9.

With the determination of Leuwiliang Village as a candidate for the government center of The West Bogor Regency, the local government will has a range of services as far as $38,94 \mathrm{~km}$ (Table 6). below describes the range of services from Leuwiliang Village as a candidate for the center of government 


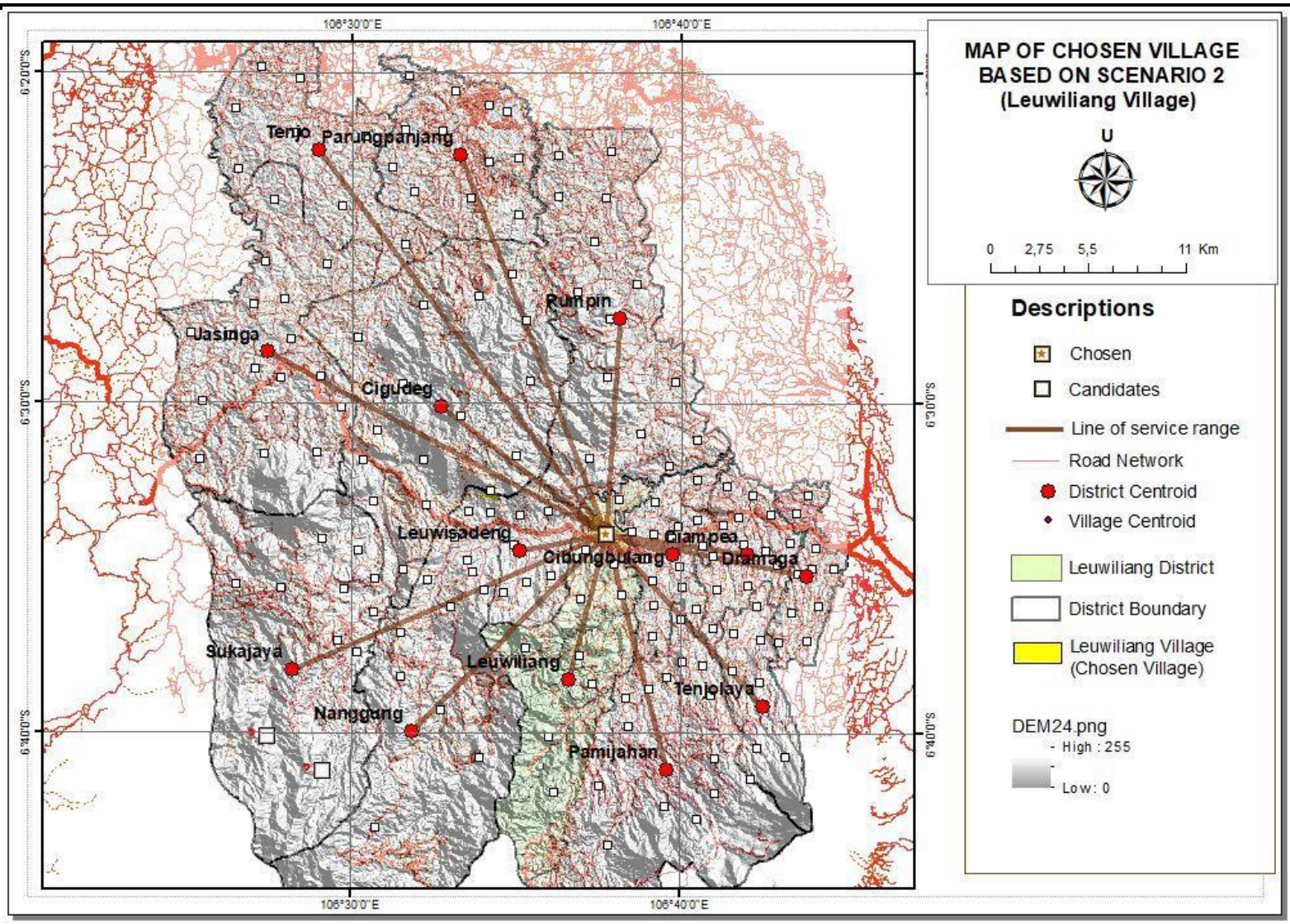

Fig. 9. Results of new location-allocation analysis based on scenario 2

Table 6. Range of Leuwiliang Village Services as a Capital City Candidate

\begin{tabular}{|c|c|c|c|c|}
\hline \multicolumn{4}{|c|}{ Location_Allocation_Desa_Leuwiliang } & \multirow{2}{*}{ Statistics of Location_Allocatio } \\
\hline FID & District - Village & Weight & Distance from Village & \\
\hline & Cibungbulang - Leuwiliang & 118193.38 & $4.68 \mathrm{~km}$ & Field \\
\hline 6 & Leuwisadeng - Leuwiliang & 62076,21 & $6,75 \mathrm{~km}$ & Distance from Vithoe \\
\hline 0 & Ciampea - Leuwiliang & 116500.28 & $10.96 \mathrm{~km}$ & \\
\hline 5 & Leuwiliang - Leuwiliang & & $13,45 \mathrm{~km}$ & Statistics: \\
\hline 2 & Cigudeg - Leuwiliang & 71862,92 & $17,18 \mathrm{~km}$ & \\
\hline 3 & Dramaga - Leuwiliang & 71,9 & $17,3 \mathrm{~km}$ & \\
\hline & Pamijahan - Leuwiliang & 80324,54 & $17,36 \mathrm{~km}$ & Maximum 38.94 \\
\hline 13 & Tenjolaya - Leuwiliang & 33234,3 & $17,49 \mathrm{~km}$ & Sum $\quad 273,32$ \\
\hline 10 & Rumpin-Leuwiliang & 78406,01 & $17,67 \mathrm{~km}$ & Mean: 19,522857 \\
\hline 7 & Nangeung - Leuwiliang & 37057,37 & $23,01 \mathrm{~km}$ & Standard Deviation 9,464996 \\
\hline 11 & Sukajaya - Leuwiliang & 20323,05 & $25,94 \mathrm{~km}$ & \\
\hline 4 & Jasinga - Leuwiliang & 30441 . & $27,4 \mathrm{~km}$ & \\
\hline 9 & Parungpanjang - Leuwiliang & 15782,79 & $35,19 \mathrm{~km}$ & \\
\hline 12 & Tenjo - Leuwiliang & 1904,69 & $38.94 \mathrm{~km}$ & \\
\hline
\end{tabular}

Based on Table 6. Parungpanjang District dan Tenjo District located at the distance as far as more then $35 \mathrm{~km}$ it means that the service range of Leuwiliang Village is further than Cigudeg Village which is less than $30 \mathrm{~km}$ away. However, when viewed from the total number of services, the total service range of Leuwiliang Village is $273.32 \mathrm{~km}$. This total is lower than the total range of cigudeg village services of $296,79 \mathrm{~km}$. The average service range of Leuwiliang Village is around 19,52 km which is lower than Cigudeg Village that has average of $21,2 \mathrm{~km}$.

\subsubsection{Mileage}

Analysis of the New closest facility by setting Leuwiliang Village, as a service center produces 14 travel routes as illustrated in Fig. 10. The blue line illustrates the shortest route from 14 districts to Leuwiliang Village vice versa.
Based on the analysis of the new closest facility, the 14 travel routes have the average mileage as described in Table 7. below.

Table 7. Average Mileage of Each District Towards Leuwiliang Village

\begin{tabular}{|c|c|c|c|c|}
\hline \multicolumn{4}{|c|}{ Travel Routes to Leuwiliang Village } & \multirow{2}{*}{ Statistics of Rute_perjalanan_Kes } \\
\hline & FID & $\begin{array}{l}\text { Travel Routes } \\
\end{array}$ & Travel Distance & \\
\hline & & Cibungbulang - Leuwiliang & $4,68 \mathrm{~km}$ & Field \\
\hline & 6 & Leuwisadeng - Leuwiliang & $6,75 \mathrm{~km}$ & \multirow{2}{*}{ Travel Distance } \\
\hline & 0 & Ciampea - Leuwiliang & $10,96 \mathrm{~km}$ & \\
\hline & 5 & Leuwiliang - Leuwiliang & $13,45 \mathrm{~km}$ & Statistics: \\
\hline & 2 & Cigudeg - Leuwiliang & $17,18 \mathrm{~km}$ & \multirow{10}{*}{\begin{tabular}{|l|l|} 
Count: & 14 \\
Minimum: & 4,68 \\
Maximum: 38,94 \\
Sum: $\quad 273,32$ \\
Mean: $\quad 19,522857$ \\
Standard Deviation: 9,464996 \\
Nulls: $\quad 0$
\end{tabular}} \\
\hline & 3 & Dramaga - Leuwiliang & $17,3 \mathrm{~km}$ & \\
\hline & 8 & Pamijahan - Leuwiliang & $17,36 \mathrm{~km}$ & \\
\hline & 13 & Tenjolaya - Leuwiliang & $17,49 \mathrm{~km}$ & \\
\hline & 10 & Rumpin - Leuwiliang & $17,67 \mathrm{~km}$ & \\
\hline & & Nanggung - Leuwiliang & $23,01 \mathrm{~km}$ & \\
\hline & 11 & Sukajaya - Leuwiliang & $25,94 \mathrm{~km}$ & \\
\hline & 4 & Jasinga - Leuwiliang & $27,4 \mathrm{~km}$ & \\
\hline & 9 & Parungpanjang - Leuwiliang & $35,19 \mathrm{~km}$ & \\
\hline & 12 & Tenjo - Leuwiliang & $38.94 \mathrm{~km}$ & \\
\hline
\end{tabular}

Statistical calculation on the shortest route from 14 districts to Leuwiliang Village as shown on the side of Table 7. shows that the shortest route is the route of Cibungbulang District - Leuwiliang Village as far as 4,8 $\mathrm{km}$. The longest route is the route of Tenjo District Leuwiliang Village, that is $38,94 \mathrm{~km}$ away. The total number of travel routes is $273.32 \mathrm{~km}$. The average route for all districts to Cigudeg Village is $19,52 \mathrm{~km}$. 


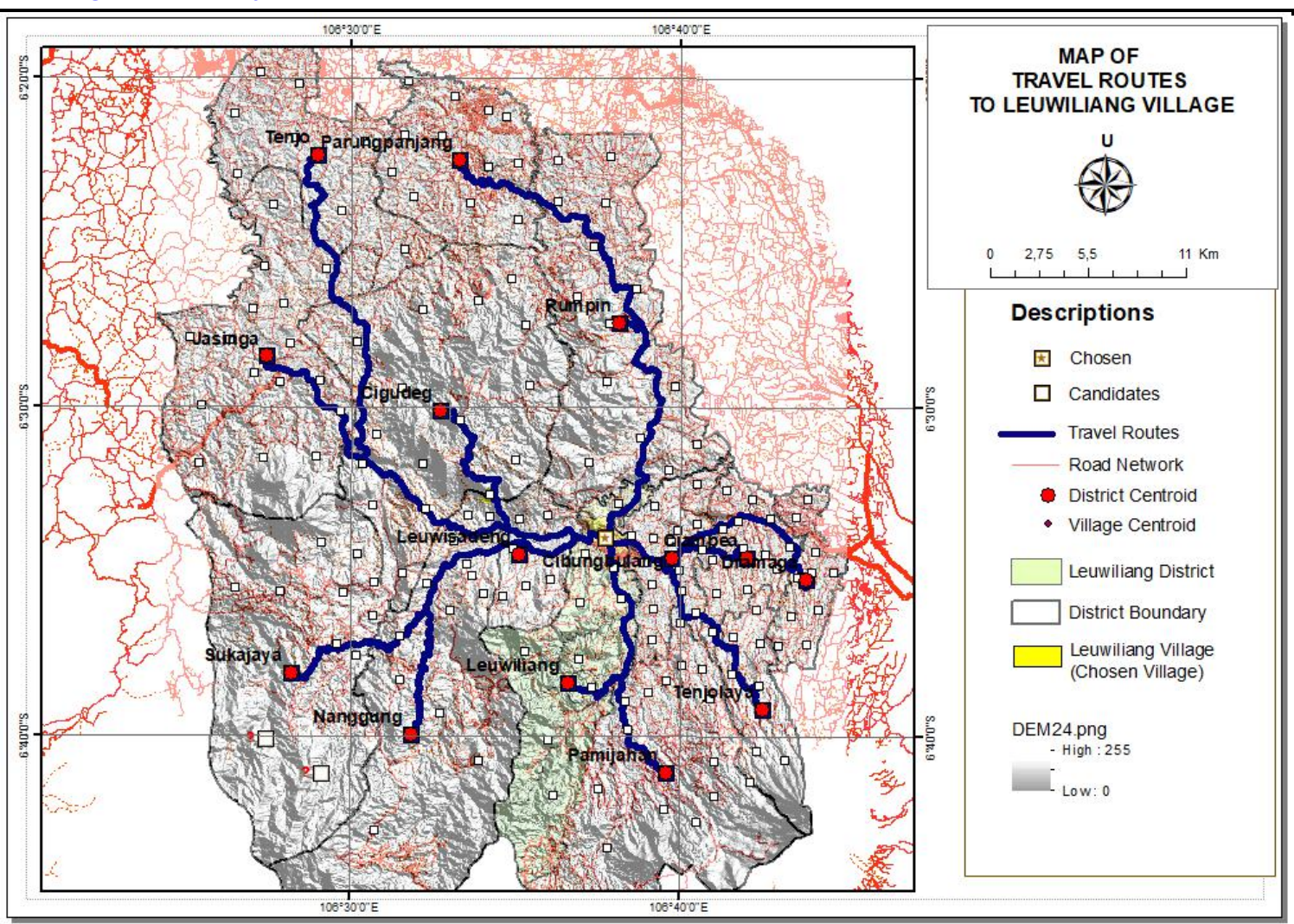

Fig. 10. Results of new closest facility analysis based on scenario 2

\subsubsection{Travel time estimation}

The following Table 8 . contains the recapitulation of travel time observations on Google Maps from 14 districts to Leuwiliang Village vice versa. It shows on the Table 8 . that the difference travel time between rush hour and nomal hour for each route is between 0,29 minute up to $-3,57$. The average travel time difference for all route is $-1,47$ minutes. The minus symbol in travel time difference indicates that during normal hour, the average speed of vehicle towards the Leuwiliang Village of tends to be slower. The time difference of only 1,47 minutes in this study can be considered insignificant so that the average daily travel time per route can be used as a benchmark for time estimation.

Table 8. Average Travel Time From 14 Districts to Leuwiliang Village Based on Google Maps

\begin{tabular}{|r|l|c|c|c|c|}
\hline \multirow{2}{*}{ No } & \multirow{2}{*}{ District } & \multicolumn{4}{|c|}{ Average Travel Time (Minutes) } \\
\cline { 3 - 6 } & & Rush Hour (S) & Normal hours (TS) & Difference & Daily \\
\hline 1 & Dramaga & 47,86 & 49,14 & $-1,29$ & 48,50 \\
\hline 2 & Cibungbulang & 17,57 & 19,57 & $-2,00$ & 18,57 \\
\hline 3 & Ciampea & 29,86 & 33,43 & $-3,57$ & 31,64 \\
\hline 4 & Leuwiliang & 31,86 & 32,86 & $-1,00$ & 32,36 \\
\hline 5 & Lewisadeng & 18,86 & 18,57 & 0,29 & 18,71 \\
\hline 6 & Pamijahan & 45,86 & 46,86 & $-1,00$ & 46,36 \\
\hline 7 & Rumpin & 43,14 & 44,00 & $-0,86$ & 43,57 \\
\hline 8 & Jasinga & 49,71 & 50,86 & $-1,14$ & 50,29 \\
\hline 9 & Parung Panjang & 77,86 & 78,86 & $-1,00$ & 78,36 \\
\hline 10 & Nanggung & 68,86 & 70,00 & $-1,14$ & 69,43 \\
\hline 11 & Cigudeg & 47,00 & 48,00 & $-1,00$ & 47,50 \\
\hline 12 & Tenjo & 91,57 & 94,00 & $-2,43$ & 92,79 \\
\hline 13 & Sukajaya & 80,29 & 82,29 & $-2,00$ & 81,29 \\
\hline 14 & Tenjolaya & 51,71 & 54,14 & $-2,43$ & 52,93 \\
\hline \multicolumn{7}{|r|}{ Total } & 702,00 & 722,57 & $-20,57$ & 712,29 \\
\hline \multicolumn{7}{|c|}{ Average } & 50,14 & 51,61 & $-1,47$ & 50,88 \\
\hline
\end{tabular}

In refer to the Table 8 . the fastest travel time occurs on the Cibungbulang District - Leuwiliang Village route with an average travel time of 18,57 minutes for the distance of $4,68 \mathrm{~km}$. The second is the Leuwisadeng District Leuwiliang Village route with a travel time of 18,57 minutes for the distance of $6,75 \mathrm{~km}$. The longest travel time occurs on the route of Tenjo District - Leuwiliang Village with an average travel time of 92,79 minutes for the distance of $38,94 \mathrm{~km}$. The second longest travel time occurred on the route of Sukajaya District - Leuwiliang Village with a travel time of 81,29 minutes for the distance of $25,94 \mathrm{~km}$. The sum of the travel time of the above 14 routes produces the average travel time to Leuwiliang Village vice versa by 50,88 minutes.

\subsubsection{Public transportation cost estimation}

The Public transportation cost that must be borne by passengers who travel from 14 districts to Leuwiliang Village vice versa can be seen in Table 9 and Table 10.

Table 9. describes in detail the transportation cost from each district to Leuwiliang Village using 2-wheeled vehicle. The table shows that the route of Cibungbulang District - Leuwiliang Village and Leuwisadeng District Leuwiliang Village route only requires a fee of IDR 12.000 and IDR 13.290 with a difference in tariff between rush hour and normal hour less than IDR 1000. On the other hand, the Tenjo District - Leuwiliang Village route need the transportation cost of IDR 134.290 followed by 2 other routes, namely Parung Panjang District - 
Leuwiliang Village with IDR. 90.360 and Sukajaya District - Leuwiliang Village with IDR 94.290.

Table 9. The Average 2 Wheeled Transportation Cost from each District to Leuwiliang Village Vice Versa

\begin{tabular}{|r|l|r|r|r|r|}
\hline \multirow{2}{*}{ No } & \multirow{2}{*}{ District } & \multicolumn{4}{|c|}{ Average GrabBike Transportation Fee (IDR x1000) } \\
\cline { 3 - 6 } & & Rush Hour (S) & Normal hours (TS) & Difference & Daily \\
\hline 1 & Dramaga & 40,14 & 38,00 & 2,14 & 39,07 \\
\hline 2 & Cibungbulang & 12,29 & 11,71 & 0,57 & 12,00 \\
\hline 3 & Ciampea & 22,14 & 25,00 & $-2,86$ & 23,57 \\
\hline 4 & Leuwiliang & 23,29 & 22,29 & 1,00 & 22,79 \\
\hline 5 & Lewisadeng & 13,43 & 13,14 & 0,29 & 13,29 \\
\hline 6 & Pamijahan & 45,29 & 44,14 & 1,14 & 44,71 \\
\hline 7 & Rumpin & 46,71 & 43,14 & 3,57 & 44,93 \\
\hline 8 & Jasinga & 81,00 & 75,43 & 5,57 & 78,21 \\
\hline 9 & Parung Panjang & 93,14 & 87,57 & 5,57 & 90,36 \\
\hline 10 & Nanggung & 77,00 & 70,57 & 6,43 & 73,79 \\
\hline 11 & Cigudeg & 54,57 & 51,57 & 3,00 & 53,07 \\
\hline 12 & Tenjo & 136,57 & 132,00 & 4,57 & 134,29 \\
\hline 13 & Sukajaya & 99,14 & 89,43 & 9,71 & 94,29 \\
\hline 14 & Tenjolaya & 49,71 & 47,86 & 1,86 & 48,79 \\
\hline \multicolumn{7}{|r|}{ Total } & 794,43 & 751,86 & 42,57 & 773,14 \\
\hline \multicolumn{7}{|c}{ Average } & 56,74 & 53,70 & 3,04 & 55,22 \\
\hline
\end{tabular}

The sum of all these routes results in an average transportation cost headed to Leuwiliang Village vice versa of IDR 55.220 with the difference in tariffs between rush hour and normal hour of IDR 3.040. This tariff difference is below the standard set by Grab which is IDR. 5000.

The following Table 10. describes the transportation cost that must be borne by passengers who traveling from the districts to Leuwiliang Village vice versa using the 4 wheeled vehicle.

Table 10. The 4Wheeled Transportation Cost from each District to Leuwiliang Village Vice Versa.

\begin{tabular}{|c|c|c|c|c|c|}
\hline \multirow{2}{*}{ No } & \multirow{2}{*}{ District } & \multicolumn{4}{|c|}{ Average GrabCar Transportation Fee (IDR x1000) } \\
\hline & & Rush Hour (S) & Normal hours (TS) & Difference & Daily \\
\hline 1 & Dramaga & 78,57 & 72,14 & 6,43 & 75,36 \\
\hline 2 & Cibungbulang & 25,43 & 23,29 & 2,14 & 24,36 \\
\hline 3 & Ciampea & 48,86 & 47,86 & 1,00 & 48,36 \\
\hline 4 & Leuwiliang & 53,14 & 48,29 & 4,86 & 50,71 \\
\hline 5 & Lewisadeng & 30,29 & 30,57 & $-0,29$ & 30,43 \\
\hline 6 & Pamijahan & 88,29 & 84,57 & 3,71 & 86,43 \\
\hline 7 & Rumpin & 70,71 & 67,43 & 3,29 & 69,07 \\
\hline 8 & Jasinga & 115,29 & 107,57 & 7,71 & 111,43 \\
\hline 9 & Parung Panjang & 148,43 & 143,71 & 4,71 & 146,07 \\
\hline 10 & Nanggung & 104,71 & 99,57 & 5,14 & 102,14 \\
\hline 11 & Cigudeg & 93,29 & 86,00 & 7,29 & 89,64 \\
\hline 12 & Tenjo & 175,14 & 178,57 & $-3,43$ & 176,86 \\
\hline 13 & Sukajaya & 131,57 & 120,86 & 10,71 & 126,21 \\
\hline 14 & Tenjolaya & 96,29 & 87,71 & 8,57 & 92,00 \\
\hline & Total & 1260,00 & 1198,14 & 61,86 & 1229,07 \\
\hline & Average & 90,00 & 85,58 & 4,42 & 87,79 \\
\hline
\end{tabular}

Similar to the 2-wheeled transportation mode, the lowest transportation cost occurs on the Cibungbulang District Leuwiliang Village route which is IDR 24.360 with a difference in tariff of IDR 2.140. The second lowest is the Leuwisadeng District - Leuwiliang Village route with a fare of IDR 30.430 and tariff difference of IDR 210. The highest transportation cost is also experienced by the Tenjo District - Leuwiliang Village route with the amount of IDR 176.860 with a difference in tariff of IDR 3.430 .

The sum of the 14 transportation costs for the 4-wheeled transportation mode results in an average transportation cost of IDR 87.790 with an average tariff difference of IDR 4.420, which is still under the Grab standard.

\subsection{Scenario 3}

For the scenario 3, 15 villages in the Cigudeg District were involved together with the geographic centroid of West Bogor Regency and promoted to be candidates. The new location-allocation analysis in this scenario determined the geographic centroid of West Bogor Regency as the chosen location. Since the geographic centroid of West Bogor Regency located at the southern part of Bayuresmi Village, we call this centroid by the name Bayuresmi 2. The result of new location-allocation analysis of this third scenario can be visually seen on Fig. 11. 


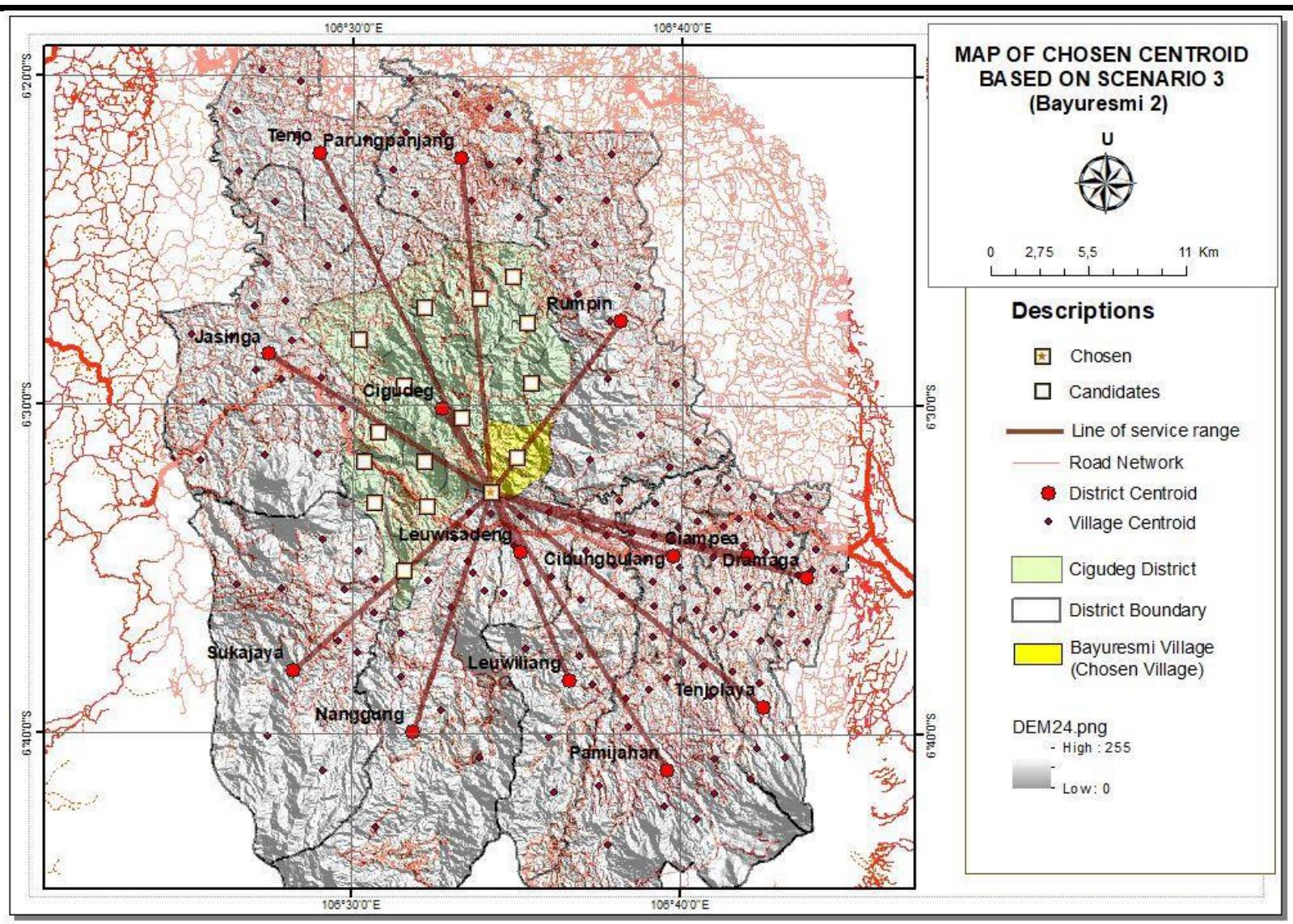

Fig. 11. Results of new location-allocation analysis based on scenario 3

With the election of Bayuresmi 2 as a candidate for the government center of West Bogor Regency, this government center will have a range of services as shown in Table 11.

Table 11. Range of Services of Bayuresmi 2 as a Capital City Candidate

\begin{tabular}{|c|c|c|c|c|}
\hline \multicolumn{4}{|c|}{ Location_allocation_Bayuresmi_2 } & \multirow{3}{*}{$\begin{array}{l}\text { Fineld } \\
\text { Destance fion Viage }\end{array}$} \\
\hline FID & \begin{tabular}{|l} 
District Village \\
\end{tabular} & Weight & Distance from Village & \\
\hline & Leuwisadeng - Bayuresmi 2 & 64968,46 & $5,2 \mathrm{~km}$ & \\
\hline 2 & Cigudeg - Bayuresmi 2 & 100411,8 & $8,12 \mathrm{~km}$ & \multirow{8}{*}{ 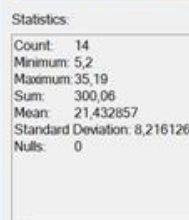 } \\
\hline & Cibungbulang - Bayuresmi 2 & 90891,76 & $12,84 \mathrm{~km}$ & \\
\hline & Ciampea - Bayuresmi 2 & 83764,25 & $19,12 \mathrm{~km}$ & \\
\hline & Nanggung - Bayuresmi 2 & 44983,18 & $19,37 \mathrm{~km}$ & \\
\hline & Leuwiliang - Bayuresmi 2 & 57176,52 & $21,31 \mathrm{~km}$ & \\
\hline 10 & Rumpin-Bayuresmi 2 & 62402,85 & $22,23 \mathrm{~km}$ & \\
\hline 11 & Sukajaya - Bayuresmi 2 & 25577,60 & $22,31 \mathrm{~km}$ & \\
\hline & Jasinga - Bayuresmi 2 & 40442,66 & $23,26 \mathrm{~km}$ & \\
\hline & Pamijahan - Bayuresmi 2 & 52461,53 & $25,21 \mathrm{~km}$ & \multirow[t]{5}{*}{ s } \\
\hline & Dramaga - Bayuresmi 2 & 40405,92 & $25,45 \mathrm{~km}$ & \\
\hline 13 & Tenjolaya - Bayuresmi 2 & 21186,05 & $25,65 \mathrm{~km}$ & \\
\hline 12 & Tenjo-Bayuresmi 2 & 9326,613 & $34,8 \mathrm{~km}$ & \\
\hline 9 & Parungpanjang - Bayuresmi 2 & 15799,19 & $35,19 \mathrm{~km}$ & \\
\hline
\end{tabular}

Table 11. shows that if Bayuresmi 2 elected as the government center, then the local government must serve the needs of the community for more than $35 \mathrm{~km}$ away from the regency capital. The statistical calculation shows that Bayuresmi 2 has the shortest range of service of $5,2 \mathrm{~km}$. The longest range of service is $35,19 \mathrm{~km}$ away. The total range of service reach $300,6 \mathrm{~km}$. The average service range is $21,05 \mathrm{~km}$. For the furthest service range, Bayuresmi 2 has a range of services closer than Leuwiliang Village $(38,94 \mathrm{~km})$ but is much farther than Cigudeg Village $(29,03 \mathrm{~km})$. However, in terms of the total service range, Bayuresmi 2 has the longest service range $(300,06 \mathrm{~km})$ compared to Cigudeg Village $(296,80 \mathrm{~km})$ and Leuwiliang Village $(273,32 \mathrm{~km})$ 


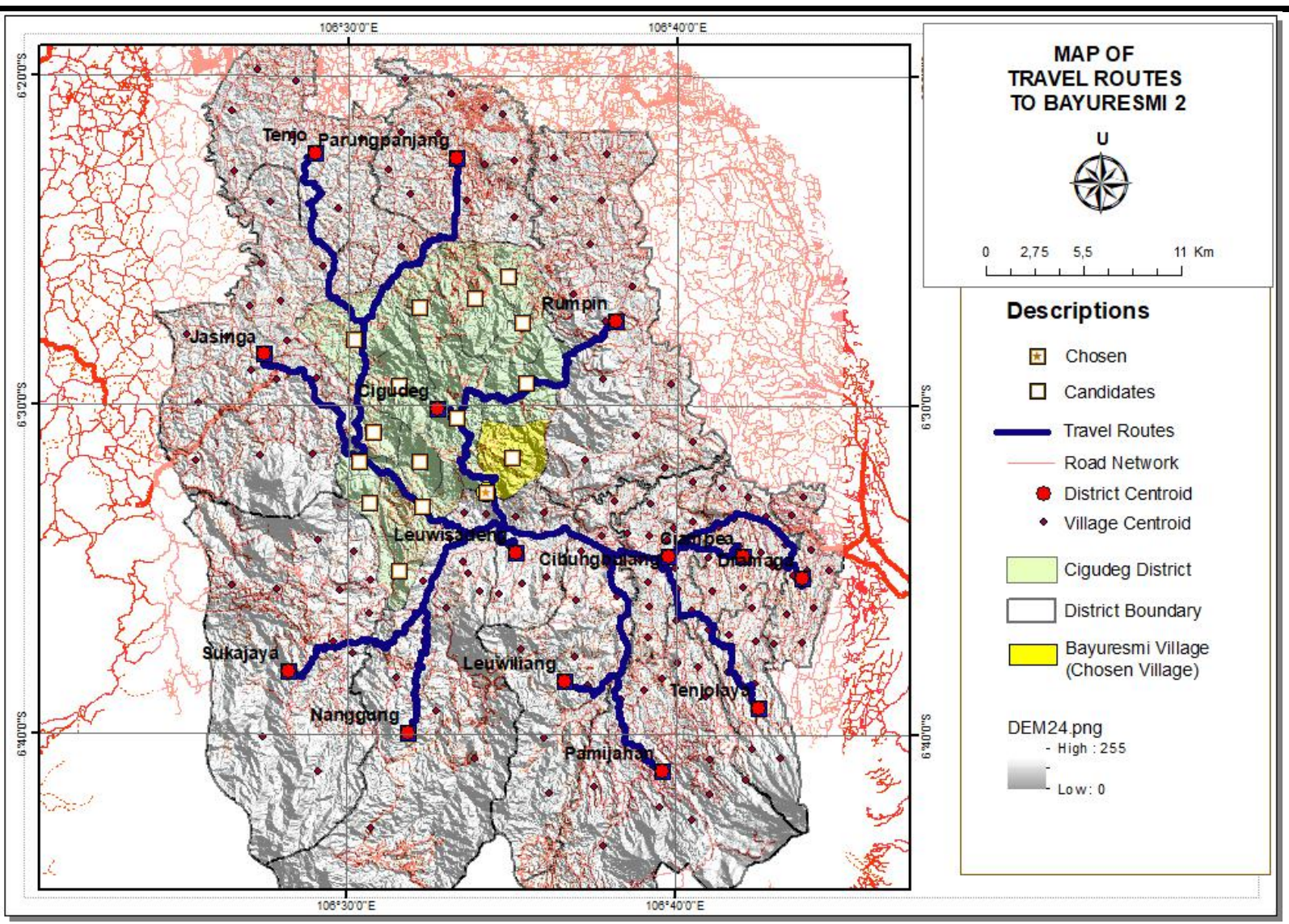

Fig. 12. Results of new closest facility analysis based on scenario 3

\subsubsection{Mileage}

Based on the result of new closest facility, the shortest route to reach Bayuresmi 2 from each district is as shown visually in the Fig. 12. The blue line is the shortest routes connecting Bayuresmi 2 with each district. These routes have mileage as shown in Table 12.

Table 12. Travel Routes 14 Districts to Bayuresmi 2

\begin{tabular}{|c|c|c|c|}
\hline \multicolumn{3}{|c|}{ Travel Route to Bayuresmi2 } & \multirow{2}{*}{$\begin{array}{l}\text { Field } \\
\text { ITevel Dstance }\end{array}$} \\
\hline FI & \begin{tabular}{|l} 
Travel Route \\
\end{tabular} & Travel Distance & \\
\hline 6 & Leuwisadeng - Bayuresmi 2 & $5,2 \mathrm{~km}$ & \\
\hline 2 & Cigudeg - Bayuresmi 2 & $8,12 \mathrm{~km}$ & Statistics: \\
\hline 1 & Cibungbulang - Bayuresmi 2 & $12,84 \mathrm{~km}$ & Count: 14 \\
\hline 0 & Ciampea - Bayuresmi 2 & $19,12 \mathrm{~km}$ & Maximum $-35,19$ \\
\hline 7 & Nanggung - Bayuresmi 2 & $19,37 \mathrm{~km}$ & $\begin{array}{ll}\text { Sum: } & 300,06 \\
\text { Mean } & 21432857\end{array}$ \\
\hline 5 & Leuwiliang - Bayuresmi 2 & $21,31 \mathrm{~km}$ & Standard Deviation 8,216126 \\
\hline 10 & Rumpin - Bayuresmi 2 & $22,23 \mathrm{~km}$ & \\
\hline 11 & Sukajaya - Bayuresmi 2 & $22,31 \mathrm{~km}$ & \\
\hline 4 & Jasinga - Bayuresmi 2 & $23,26 \mathrm{~km}$ & \\
\hline 8 & Pamijahan - Bayuresmi 2 & $25,21 \mathrm{~km}$ & $<$ \\
\hline 3 & Dramaga - Bayuresmi 2 & $25,45 \mathrm{~km}$ & \\
\hline 13 & Tenjolaya - Bayuresmi 2 & $25,65 \mathrm{~km}$ & \\
\hline 12 & Tenjo - Bayuresmi 2 & $34,8 \mathrm{~km}$ & \\
\hline 9 & Parungpanjang - Bayuresmi 2 & $35,19 \mathrm{~km}$ & \\
\hline
\end{tabular}

Statistical calculations on Table 12. shows that the shortest route is the route from Leuwisadeng District to Bayuresmi2, that is $5,2 \mathrm{~km}$. The farthest route is the route from Parung Panjang District to Bayuresmi2 that is 35,19 $\mathrm{km}$. The total number of travel routes from all districts to bayuresmi 2 is $300,06 \mathrm{~km}$ with an average value of 21,43 $\mathrm{km}$.

\subsubsection{Travel time estimation}

The following Table 13. describes in detail the travel time needed to travel to Bayuresmi 2 on the above 14 routes.

Table 13. Travel Time Average Travel from 14 Districts to Bayuresmi2 Based on Google Maps

\begin{tabular}{|c|c|c|c|c|c|}
\hline \multirow{2}{*}{ No } & \multirow{2}{*}{ District } & \multicolumn{4}{|c|}{ Average Travel Time (Minutes) } \\
\hline & & Rush Hour (S) & Normal hours (TS) & Difference & Daily \\
\hline 1 & Dramaga & 81,00 & 80,00 & 1,00 & 80,50 \\
\hline 2 & Cibungbulang & 52,00 & 52,71 & $-0,71$ & 52,36 \\
\hline 3 & Ciampea & 62,71 & 65,57 & $-2,86$ & 64,14 \\
\hline 4 & Leuwiliang & 60,71 & 62,43 & $-1,71$ & 61,57 \\
\hline 5 & Lewisadeng & 42,14 & 42,14 & 0,00 & 42,14 \\
\hline 6 & Pamijahan & 77,43 & 80,14 & $-2,71$ & 78,79 \\
\hline 7 & Rumpin & 77,29 & 79,29 & $-2,00$ & 78,29 \\
\hline 8 & Jasinga & 54,14 & 54,86 & $-0,71$ & 54,50 \\
\hline 9 & Parung Panjang & 81,29 & 82,57 & $-1,29$ & 81,93 \\
\hline 10 & Nanggung & 77,29 & 77,29 & 0,00 & 77,29 \\
\hline 11 & Cigudeg & 18,29 & 18,57 & $-0,29$ & 18,43 \\
\hline 12 & Tenjo & 96,86 & 97,86 & $-1,00$ & 97,36 \\
\hline 13 & Sukajaya & 87,71 & 88,71 & $-1,00$ & 88,21 \\
\hline 14 & Tenjolaya & 84,43 & 87,86 & $-3,43$ & 86,14 \\
\hline & Total & 953,29 & 970,00 & $-16,71$ & 961,64 \\
\hline & Average & 68,09 & 69,29 & $-1,19$ & 68,69 \\
\hline
\end{tabular}

It can be seen on the Table 13, that the fastest travel time occurred on the route of the Cigudeg District - Bayuresmi 2 with a travel time of 18,43 minutes for a distance of $8,12 \mathrm{~km}$. The second fastest travel time occurs on the route of Leuwisadeng District - Bayuresmi 2 with a travel time of 42,14 minutes for a distance of only $5,2 \mathrm{~km}$. The table also explains that the longest travel time occurs on 
the route of Tenjo District - Bayuresmi2 with a travel time of 97.36 minutes for a distance of $34,8 \mathrm{~km}$. The second longest travel time occurs on the route of Sukajaya District - Bayuresmi 2 with a travel time of 88,21 minutes for a distance of $22,31 \mathrm{~km}$. The difference in travel time between rush hour and normal hour seems to be no significant (-1,19 minutes). Therefore, the average daily travel time can be used as a benchmark for travel time estimation. The total daily travel time to go to Bayuresmi 2 is 961,41 minutes with an average daily travel time of 68.69 minutes

\subsubsection{Public transportation costs}

This Table 14. describes the cost of public transportation for 2-wheeled transportation modes that must be borne by passengers who traveling from district to Bayuresmi 2 and vice versa.

Table 14. The Average 2 Wheeled Transport Costs from each district to Bayuresmi 2 Vice Versa

\begin{tabular}{|r|l|r|r|r|r|}
\hline \multirow{2}{*}{ No } & \multirow{2}{*}{ District } & \multicolumn{4}{|c|}{ Average GrabBike Transportation Fee (IDR x1000) } \\
\cline { 3 - 6 } & & Rush Hour (S) & Normal hours (TS) & Difference & \multirow{2}{*}{ Daily } \\
\hline 1 & Dramaga & 91,57 & 86,86 & 4,71 & 89,21 \\
\hline 2 & Cibungbulang & 50,43 & 44,71 & 5,71 & 47,57 \\
\hline 3 & Ciampea & 62,86 & 65,00 & $-2,14$ & 63,93 \\
\hline 4 & Leuwiliang & 63,57 & 60,00 & 3,57 & 61,79 \\
\hline 5 & Lewisadeng & 36,86 & 34,00 & 2,86 & 35,43 \\
\hline 6 & Pamijahan & 95,71 & 80,43 & 15,29 & 88,07 \\
\hline 7 & Rumpin & 88,43 & 81,86 & 6,57 & 85,14 \\
\hline 8 & Jasinga & 69,86 & 66,43 & 3,43 & 68,14 \\
\hline 9 & Parung Panjan & 119,29 & 110,86 & 8,43 & 115,07 \\
\hline 10 & Nanggung & 70,43 & 67,43 & 3,00 & 68,93 \\
\hline 11 & Cigudeg & 11,00 & 11,00 & 0,00 & 11,00 \\
\hline 12 & Tenjo & 136,43 & 125,14 & 11,29 & 130,79 \\
\hline 13 & Sukajaya & 92,14 & 87,43 & 4,71 & 89,79 \\
\hline 14 & Tenjolaya & 99,43 & 92,86 & 6,57 & 96,14 \\
\hline \multicolumn{7}{|r|}{ Total } & 1088,00 & 1014,00 & 74,00 & 1051,00 \\
\hline \multicolumn{7}{|r|}{ Average } & 77,71 & 72,43 & 5,29 & 75,07 \\
\hline
\end{tabular}

For the case of scenario 3 as it shown in the Table 14, there is a slightly significant difference in transportation costs during rush hour and normal hour with a range between IDR. 0 up to IDR 15.290 or an average of IDR 5.290 .

Table 14. also shows that the route of the Tenjo District Bayuresmi 2 requires transportation costs of IDR 130.000 for mileage of $34,8 \mathrm{~km}$ with travel time of 97,36. This is the highest transportation costs among 14 routes. The second highest transportation cost occurs on the route of Parung Panjang District - Bayuresmi 2 at a cost of IDR 115.070. The total daily public transportation cost to Bayuresmi2 using 2 wheeled vehicle reach IDR 1.051.000 or an average of IDR 75.070.

The following Table 15. describes the cost of 4-wheeled public transportation modes that must be borne by passengers when traveling from the district to Bayuresmi 2 and vice versa. Referring to data shown in Table 15. the difference in tariffs between rush hour and normal hour varies greatly from IDR. - 570 - up to IDR 18.430. or an average of IDR 6.170. Furthermore, the lowest transportation cost occurs on the route of Cigudeg Dis trict - Bayuresmi 2 at a cost of IDR 21.710, with the difference in tariff of IDR -570 .

Table 15. The Average 4 Wheeled Transport Costs from each District to Bayuresmi 2 Vice Versa.

\begin{tabular}{|c|c|c|c|c|c|}
\hline \multirow{2}{*}{ No } & \multirow{2}{*}{ District } & \multicolumn{4}{|c|}{ Average GrabCar Transportation Fee (IDR x1000) } \\
\hline & & Rush Hour (S) & Normal hours (TS) & Difference & Daily \\
\hline 1 & Dramaga & 124,43 & 114,71 & 9,71 & 119,57 \\
\hline 2 & Cibungbulang & 80,14 & 70,71 & 9,43 & 75,43 \\
\hline 3 & Ciampea & 93,57 & 93,00 & 0,57 & 93,29 \\
\hline 4 & Leuwiliang & 90.57 & 87,86 & 2,71 & 89,21 \\
\hline 5 & Lewisadeng & 57,43 & 56,71 & 0,71 & 57,07 \\
\hline 6 & Pamijahan & 129,57 & 111,14 & 18,43 & 120,36 \\
\hline 7 & Rumpin & 118,00 & 112,71 & 5,29 & 115,36 \\
\hline 8 & Jasinga & 93,43 & 90,71 & 2.71 & 92.07 \\
\hline 9 & Panung Panjang & 148,14 & 137,43 & 10.71 & 142,79 \\
\hline 10 & Nanggung & 104,00 & 101,57 & 2,43 & 102,79 \\
\hline 11 & Cigudeg & 21,43 & 22,00 & $-0,57$ & 21,71 \\
\hline 12 & Tenjo & 164,57 & 154,57 & 10,00 & 159,57 \\
\hline 13 & Sukajaya & 127,00 & 122,29 & 4,71 & 124,64 \\
\hline 14 & Tenjolaya & 135,00 & 125,43 & 9,57 & 130,21 \\
\hline & Total & 1487.29 & 1400,86 & 86,43 & 1444,07 \\
\hline & Average & 106.23 & 100,06 & 6,17 & 103,15 \\
\hline
\end{tabular}

Eight travel routes from 14 existing routes spend transportation cost above IDR 100.000 with the highest fare of IDR 159.570 that is for the Tenjo District Bayuresmi 2 route. Five other routes require transportation costs between IDR 50.000 up to IDR 95.000. The total amount of daily public travel cost using 4-wheeled vehicles from 14 districts to Bayuresmi 2 is 1.444 .070 or an average of 103.150

\subsection{Accessibility Analysis}

A simple statistical comparison method used in this accessibility analysis was arranged in a table form as shown in Table 16. The comparable parameters include; (1) travel distance; (2) travel time; (2) 2-wheeled public transportation cost; and (4) 4-wheeled public transportation cost. The value of each parameter that was compared is the average value.

Table 16. Travel Distance, Travel Time and Public Transportation Cost of the Three Scenarios

\begin{tabular}{|l|c|c|c|c|}
\hline \multirow{2}{*}{ Chosen Village } & \multicolumn{4}{|c|}{ Accessibility Parameter } \\
\cline { 2 - 5 } & $\begin{array}{c}\text { Distance } \\
(\mathrm{Km})\end{array}$ & $\begin{array}{c}\text { Travel Time } \\
\text { (Minute) }\end{array}$ & $\begin{array}{c}\text { 2-Wheeled Cost } \\
\text { (IDR x1000) }\end{array}$ & $\begin{array}{c}\text { 4-Wheeled Cost } \\
\text { (IDR x1000) }\end{array}$ \\
\hline Cigudeg & 21,20 & 54,23 & 64,30 & 94,65 \\
\hline Leuwiliang & 19,52 & 50,88 & 55,22 & 87,79 \\
\hline Bayuresmi 2 & 21,43 & 68,69 & 75,07 & 103,15 \\
\hline
\end{tabular}

Based on the Table 16. Leuwiliang Village has the lowest value for all parameters of accessibility. The second order is held by Cigudeg Village, while the third order is held by Bayuresmi 2. Figure 13. is a graph describes visually the comparis on of accessibility parameters from three selected villages. 


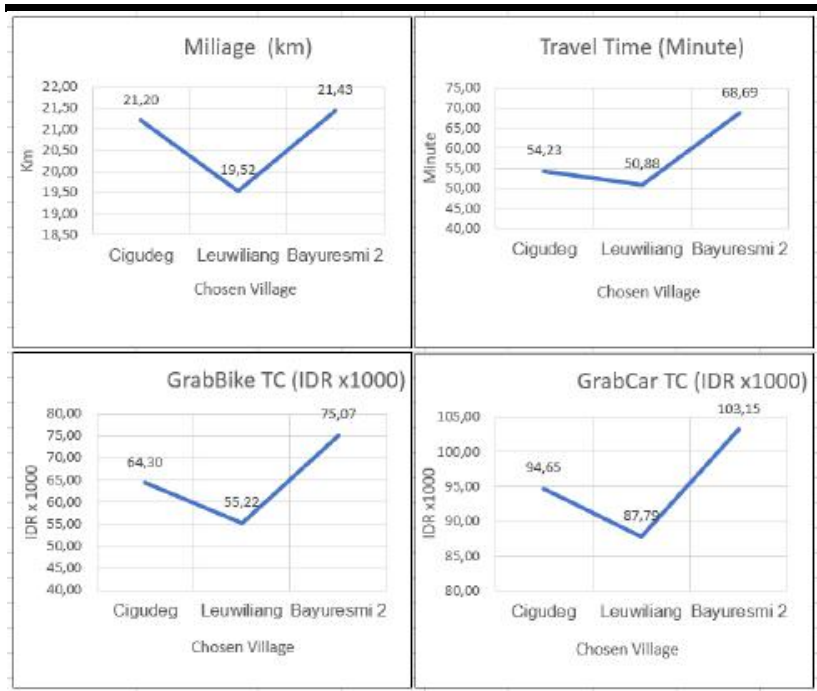

Fig. 13. Graph of accessibility parameters of Cigudeg

Village, Leuwiliang Village and Bayuresmi 2

\section{DISCUSSION}

The results of comparative analysis presented in the form of tabulation and graphs show that Leuwiliang Village has accessibility parameters with the lowest value for all parameters (travel distance, travel time and public transportation cost). Bayuresmi 2 as it shown on Table 16. has accessibility parameters with the highest value for all parameters. While Cigudeg Village has accessibility parameters with values between Leuwiliang Village and Bayuresmi 2 for all parameters.

In Refer to accessibility criteria which mention that the closer the origin and destination to the transportation system, the higher the level of accessibility, and the less time and money spent on the trip, the greater the accessibility [18], Leuwiliang Village seems to be a village that meets these criteria. In other word, Leuwiliang Village has the highest level of accessibility compared to Cigudeg Village and Bayuresmi 2.

The status of Leuwiliang Village as a village with the highest level of accessibility has actually been detected by only looking at the total range of services, when referring to the argument that states that the capital or location chosen must have the smallest total physical distance so that it is easily accessible from all regions for smooth service in government services [19].

If we look at the Service Range Table in the three scenarios, Cigudeg Village has a total range of services of $296.80 \mathrm{~km}$ (Table 3). Leuwiliang Village has the total range of services of $273.32 \mathrm{~km}$ (Table 7.), and Bayuresmi 2 with a total range of services of $300.06 \mathrm{~km}$ (Table 11).

It is clear that of the three total service ranges, the village of Leuwiliang has the shortest total service range. This can be interpreted that among the three selected locations, Leuwiliang Village is in the most appropriate location to become the center of government of West Bogor Regency.

The choice of Leuwiliang Village as the most suitable village to become the candidate for the capital of West Bogor Regency in this study, raises one question. What was the basis of the expert team in 2008 in determining the village of Cigudeg as the candidate for the capital of West Bogor Regency?

In an interview with a member of the expert team involved in the Cigudeg Village study in 2008, said that the determination of Cigudeg Village of was based on the index of centrality. The centrality index is one of the methods used in regional planning, which is usually used in conjunction with scalogram methods, analys is of cities, gravity and other methods [21]. When was questioned is not the centrality index based on the completeness of the infrastructure facilities, while the facts show that the complete infrastructure facilities of the Cigudeg Village are not as complete as Leuwiliang Village, he replied that the main reason was to find areas that are still empty.

This main reason indirectly leads to a conclusion that the appointment of Cigudeg Village as a candidate for the capital in 2008 was based more on political considerations. The choice of territory on the basis of political considerations is permissible in regional planning (Regional Layout Plans) as long as it does not conflict with the allocation of space in the spatial pattern. In the interview, he was also asked if he was basically looking for vacant land, why was not choose Bayuresmi Village which is the centroid of West Bogor Regency. The reason given was that Bayuresmi Village is located in a hilly area.

Even though there has been an answer that Bayuresmi Village was not chosen for topographic reasons, this study still proposes Bayuresmi 2 as a candidate for the capital (scenario 3). There are 3 reasons that support the need for centroid points in West Bogor Regency to be included in the selection of capital candidates. First, existing technology makes it possible to modify landscapes through civil engineering. Second, many countries move their capital to the center of the region on the basis of balance and equal distribution of services [18]. Third, many cities in Indonesia are in hilly areas which with the correct city arrangement produce beautiful urban areas.

This research actually expects Bayuresmi 2 to be chosen as the location of the prospective capital city with the highest level of accessibility. Unfortunately, the results of the analysis on each accessibility parameter put Bayuresmi 2 in third place. The failure of Bayuresmi 2 to be in the first position is certainly related to the availability of the existing road network around Bayuresmi 2. 
The failure of Bayuresmi 2 to be in the first position is certainly related to the availability of the existing road network around Bayuresmi 2. We can see clearly in Fig. 14 that of the 14 routes to Bayuresmi 2, only one route that has a direct connection to Bayuresmi 2, that is Rumpin District. 13 other routes must pass through Leuwiliang Village or Cigudeg Village. These 13 routes also utilize the Bogor Rangkasbitung collector road which is also used by the route to Cigudeg Village and towards Leuwiliang Village. Bayuresmi 2 is also in a position of approximately $3 \mathrm{~km}$ from the Bogor Rangkasbitung collector road. Such conditions certainly impact on the addition of the length of the 13 routes, and enlarge the total route distance to Bayuresmi2.

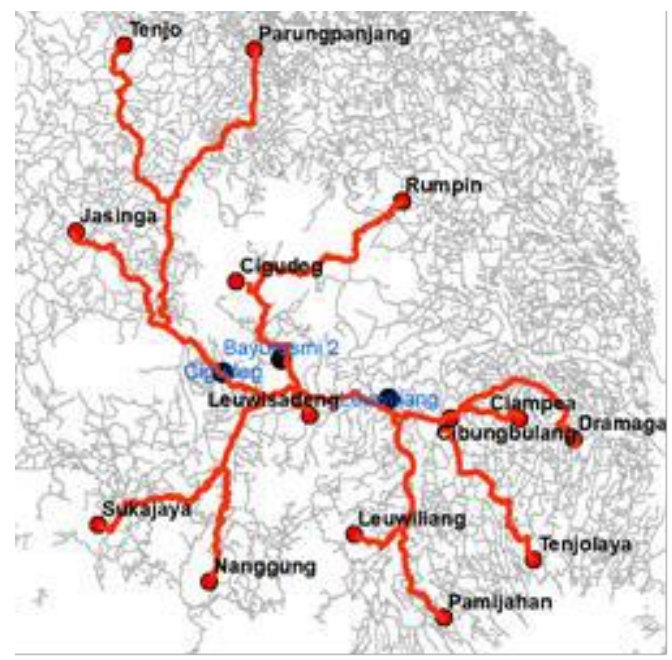

Fig. 14. Availability ofroad network around Bayuresmi 2

The level of accuracy of the research results using network analyst is highly dependent on the availability and accuracy of road network data and traffic engineering data. Accuracy of attributes in the classification of road functions will clearly separate the road that can be passed by motorized vehicles and roads that can only be passed on foot. Accuracy in this case will affect the determination of the shortest route by motorized vehicles Accuracy of traffic engineering data, such as one-way or two-way roads, the presence of red lights, prohibition to turn, prohibition to make U-turn will also affect the selection of the shortest route.

In this study, errors caused by traffic engineering could be considered very small, because there is no one-way road implementation, no restricted turn, no U-turn ban and only a few red lights are found in the West Bogor Regency. In contrast to the road network, there are differences in data presented by network analyst with data presented by Google Maps.

The Fig. 18 is an example of the difference in distance that occurs on the Bayuresmi 2 - Rumpin District route. According to Google Maps the shortest distance route
Bayuresmi 2 - District Rumpin is $27,1 \mathrm{~km}$, while according to the new closest facility $22,23 \mathrm{~km}$ (Table 12 ). The route taken by the two is also different. In this case, because Google data is always updated [34], and each road segment is corrected through field checks, it is suspected that error occur in the road function classification system of the road layer of topographical map.

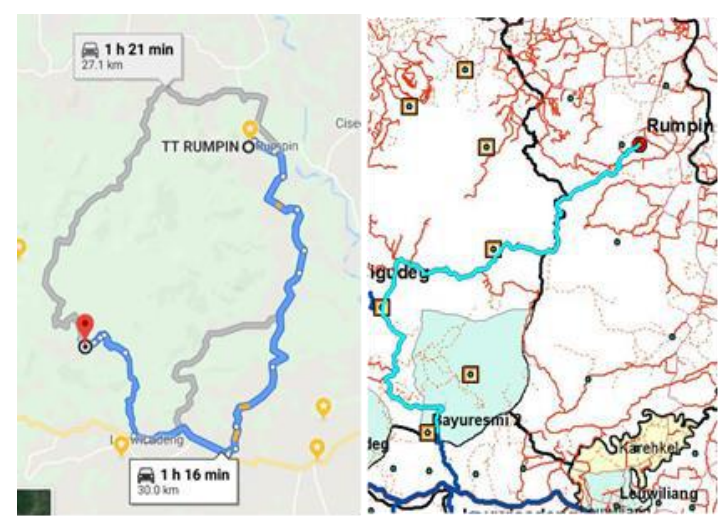

Fig. 15. Route selection presented by Google Maps and by network analyst

It is suspected that the road segment that should actually function as a trail is grouped into motorized road functions. This error clearly influences the accuracy of the Bayuresmi 2 accessibility parameters.

Network analysis, actually also equipped with the ability to estimate travel time. However, to be able to estimate the travel time, network analyst requires the daily road profile data (street daily profile). Compiling such network datasets requires extensive data collection and processing, which can be very expensive or not feasible for some applications [34]. The difficulty in compiling the daily road profile table also seems to be the cause of the lack of network analyst used in spatial analysis. Therefore, in this study, the estimation of travel time was done using the Google Maps application.

\subsection{Google Maps as a tool for estimation of travel time}

On the research of Estimating O-D Travel Time Matrix by Google Maps API [34] they found several benefits of using Google Maps in estimating travel time compared to ArcGIS Network Analyst. These advantages include: (1) no need to prepare a road network; (2) using a newer road network; and (3) calculating congestion in high traffic and rush hour areas. But they also alluded the weaknesses of using Google Maps, for instance all data used in calculations is managed by Google Maps. Users do not have control over any quality or editing rights, while it is believed that there is no data entirely error-free [34]. 
The advantages of Google Maps were indeed proven in this research. Without having to prepare time-consuming data, and simply open the Google Maps application on a smartphone, then determine the place of origin and destination, Google Maps instantly provides data on the route, and travel time according to the mode of transportation used. The data presented is definitely a real time data.

Google is also able to offer alternative routes that can be chosen according to the behavior of the traveler. Fig. 18 is an example of how Google offers 3 alternative routes that can be chosen to travel from Bayuresmi2 to Rump in District with 4 wheeled private transportation modes. The first route is $27.1 \mathrm{~km}$ with a travel time of 1 hour 21 minutes, the second and third routes are $30,0 \mathrm{~km}$ with a travel time of 1 hour 16 minutes. The three routes offered by Google are even different from the shortest route set by the network analyst with a distance of $22.23 \mathrm{~km}$ (Table 12). For the public transportation mode Google only offers a route with the fastest travel time. In the above case, Google offers a route with a distance of $30.0 \mathrm{~km}$ with a travel time of 1 hour 16 minutes.

In relation to the level of accessibility of a place or location, Google Maps is clearly able to offer a number of route options, complete with the estimated travel time and distance, including the modes of transportation used. This Google Maps offer, indirectly provides many options for travelers to choose whether based on the fastest time or the shortest distance, and the mode of transportation used. These Google Maps capabilites contribute greatly in determining the level of accessibility of a place. Logically, the more routes offered, and the more choices of transportation modes that can be used, the greater the opportunity or access to reach the place, which means the higher the level of accessibility of the place. Therefore, regardless of the level of data accuracy as questioned [34]. Estimating travel time and distance with the Google Maps application seems to be more effective and efficient with a more accountable degree of accuracy.

Regrettably, Google Maps is not equipped with an analysis function as found on network analyst. The new location-allocation analysis function in this study clearly contains errors due to the quality of road data that still has to be questioned. Difference in distance as in the case of the shortest distance Bayuresmi 2 - Rumpin District is evidence of an error in road data derived from the Indonesian topographic map.

\subsection{Grab application as a tool for estimation of public transport cost.}

Network analyst, basically also equipped with the ability to estimate the cost of travel. But as well as travel time, procurement of travel cost data requires the cost of survey and processing data that is very large and complex.
Therefore, the presence of online transportation services is considered as a way out in data collection of public transportation cost estimation.

The main reason for using online transportation services in estimating public transportation cost is because these modern service models are in great demand by all levels of society, and are expected to become models of future transportation services. The tariff system issued by online transportation services that must be paid by passengers indirectly represents a system of public transport fares that can be accepted by the public. Another reason is that the door-to-door service system implemented by online transportation services is able to eliminate un-measured travel costs such as those that occur in travel systems based on stops and routes. Therefore, the estimation of public transportation cost using online transportation services is more measurable and realistic and simultaneously reflects the total cost of travel from the place of origin to the destination.

The estimation of public transportation cost based on the Grab application used in this study is known to not always be in-line with the recommended route offered by Google Maps for public transportation. Fig. 16 below is an example of a case that occurred on the journey from Bayuresmi 2 to Pamijahan District. It appears on the Fig. 16 that Grab took a different and farther route than the one recommended by Google Maps. This difference in distance clearly affects the total transportation costs that must be borne by passengers. The difference between the recommended route of Google Maps and the route chosen by Grab does not only occur on the route of Bayuresmi 2 - Pamijahan District, but also on other routes that are the object of research.

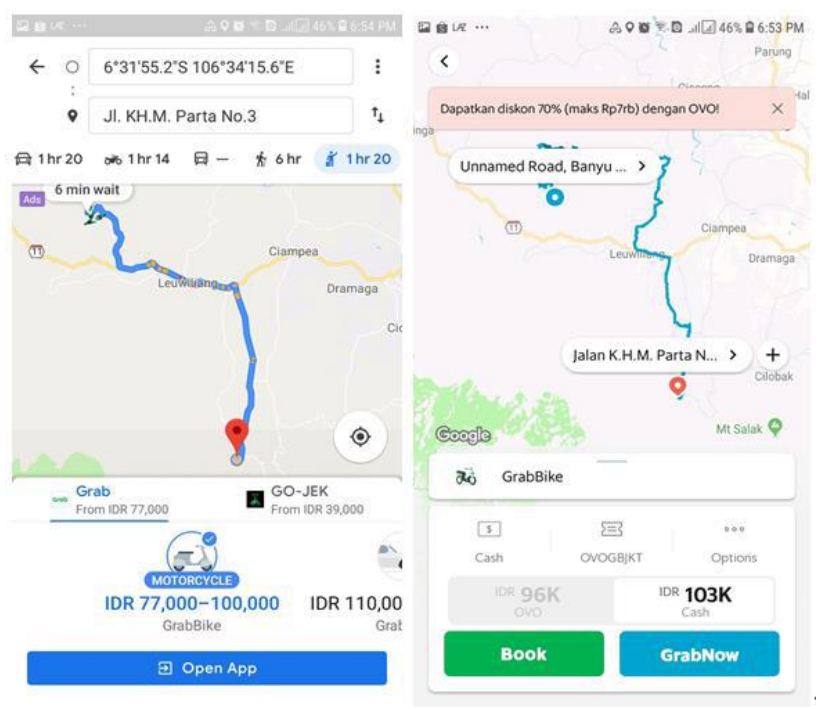

Fig. 16. Differences in travel routes between route recommended by Google Maps and route chosen by Grab 
However, the case of the different route that affects on the total cost of public transportation, as well as the case of the determination of the tariff per km which is also said to be affected by weather conditions, is not the focus of this study. Estimating public transportation costs in this study is based solely on the IDR numbers listed in the Grab application. In this study, the IDR number stated in the Grab application is considered as the official and legal transportation fee is sued by the company, as a result of an internal decision, and accepted by the passenger as service satisfaction.

\section{CONCLUSIONS}

From a series of analysis carried out in an effort to answer the research objectives, it is concluded that Cigudeg Village is not included in the village with the highest level of accessibility. The highest accessibility value is precisely held by Leuwiliang Village, the chosen village as a result of scenario 2. Bayuresmi 2, which from the beginning was expected to be the location with the highest level of accessibility apparently is only in third place.

\section{RECOMMENDATIONS}

Since the results of the research have appointed Leuwiliang Village as the village with the highest level of accessibility, it is suggested to the West Java provincial government to take more consideration in the determination of Cigudeg Village as the candidate for the capital of West Bogor Regency.

It is recommended to repeat this study by using travel data and travel time completely from Google Maps to see if there are differences in results compared to the results of the current study. This is important for network analyst development as a science that is able to adapt to technological developments.

It is recommended for coaches who involved in the network analyst training to continue to carry out various network analyst applications in solving problems related to services, and make them as materials to develop a research-based learning model that is believed to provide better understanding to participants in the learning process.

\section{ACKNOWLEDGEMENTS}

The author would like to acknowledge Dr. Al Muktabar, the Chairman of the Indonesian Coach Association and Dr. Wiwin Ambarwulan, the Head of Research, Promotion and Collaboration Center, Geospatial Information Agency, for their willingness to become supervisors and reviewers in writing this research paper.

\section{REFERENCES}

[1] Abousaeidia, M., R. Fauzib, R. Muhamad. (2016). Geographic Information System (GIS) modeling approach to determine the fastest delivery routes. Saudi Journal of Biological Sciences (2016) 23: 555-564

[2] Ahmed, S., R. F. Ibrahim, H. A. Hefny. (2017). GISBased Network Analys is for the Roads Network of the Greater Cairo Area. Proceedings of the International Conference on AppliedResearch in Computer Science and Engineering ICAR'17, Lebanon, 22-06-2017, published at http://ceur-ws.org

[3] Alfonso, J. (2017). Safe Walk: A Network Analyst Framework for Safe Routes to School. Thesis. Faculty of the USC Graduate School University of Southern California. California.

[4] Anjomshoaa, E, H. Bin Lamit, A. Shafaghat, T. H. Khan, S. S. Bt S. Mahdzar. (2017). Accessibility Measurement Techniques in Urban Studies: a Comprehensive Review. Journal of Biodiversity and Environmental Sciences (JBES) (Online) Vol. 10, No. 6: 92-106

[5] Anindhita W., M. Arisanty, D. Rahmawati. (2016). Analis is Penerapan Teknologi Komunikasi Tepat Guna Pada Bisnis Transportasi Ojek Online. Prosiding Seminar Nasional INDOCOMPAC. Universitas Bakrie, Jakarta. 2-3 Mei 2016. 713 - 729

[6] Bogor Regency Government. (2015). Cigudeg Siap Jadi Ibukota Kabupaten Bogor Barat. Retrieved from http://bogorkab.go.id/index.php/ post/detail/1767/ cigudeg-siap-jadi-ibukota-kabupaten-bogor-barat\#. XEgt7s 1S9PY.

[7] Bogor Regency Central Bureau of Statistics. (2017). Jumlah Penduduk Kabupaten Bogor Menurut Kecamatan Tahun 2014-2017. Retrieved from https://bogorkab.bps.go.id/statictable/2017/

[8] Boscoe F. P., K. A. Henry, M.1 S. Zdeb. (2012). A Nationwide Comparison of Driving Distance Versus Straight-Line Distance to Hospitals. Prof Geogr. 2012 April 1; 64(2): doi:10.1080/00330124.2011.583586

[9] Dumbliauskas V, V. Grigonis, A. Barauskas. (2017). Application of Google-based Data for Travel Time Analysis: Kaunas City Case Study. Promet Traffic\&Transportation, Vol. 29, 2017, No. 6, 613-621

[10] ESRI. (2010). Network Analyst Tutorial. Copyright (C) 1995-2010. Esri All rights reserved. Retrieved from http://help.arcgis.com/en/ arcgisdesktop/ 10.0/pdf/ network-analyst-tutorial.pdf

[11] Ford, A. C., S. L. Barr, R. J. Dawson dan P. James. (2015). Transport Accessibility Analysis Using GIS: Assessing Sustainable Transport in London. ISPRS Int. J. Geo-Inf. 2015, 4: 124-149;

[12] Geurs, K. T. dan B. van Wee. (2004). Accessibility Evaluation of Land-use and Transport Strategies: Review and Research Directions. Journal of Transport Geography 12 (2004) : 127-140 
[13] Geospasial UntukNegeri. (2019). Download Peta Per Wilayah. Retrieved from http://tanahair.indonesia. go.id/ portal-web/download/ perwilayah

[14] Harzan, M. (2015). Analsis Lokasi Optimal Pusat Pemerintahan Dalam rangka Pengembangan Wilayah di Kabupaten Buton Sulawesi Tenggara. Skripsi. Fakultas Geogarfi Univesitas Muhammadiyah. Surakarta. Retrieved from http://eprints.ums.ac.id/ 40021/1 /NASKAH\%20PUBLIKASI.pdf.

[15] Indopos. (2018). Pembentukan Bogor Barat Terganjal Moratorium DOB. Retrieved from https://www.indopos.co.id/read/2018/10/10/151942/pe mbentukan-bogor-barat-terganjal-moratorium-dob.

[16] Kwan, M.-P. (1998). Space-Time and Integral Measures of Individual Accessibility: A Comparative Analysis Using a Point-based Framework. Geographical Analysis, Vol. 30, No. 3 (July 1998) Ohio State University Press

[17] Liu S. dan X. Zhu. (2004). Accessibility Analyst: an Integrated GIS Tool for Sccessibility Analysis in Urban Trans portation Planning. Environment and Planning B: Planning and Design 2004, volume 31: 105 -124

[18] Liu, D. (2017). Multi-factor Consideration in Selection of a Capital for a Country. Asian Social Science; Vol. 13, No. 7; 2017

[19] Mahathir, A. (2017). Tinjauan Teori dan Penentuan Lokasi Kawasan Pusat Pemerintahan. Retrieved from https://www.scribd.com/document/ 362731105/ Tinjauan-Teori-Dan-Penentuan-Lokasi-Kawasan-PusatPemerintahan?doc_id=362731105 \&download $=$ true \&order $=457908855$.

[20] Miller, E.J. (2018). Accessibility: Measurement and Application in Transportation Planning. TRANSPORT REVIEWS 2018, VOL. 38, NO. 5: 551-555

[21] Muta'ali, L. (2013). Penataan Ruang Wilayah dan Kota (Tinjauan Normatif - Teknis). Badan Penerbit Fakultas Geografi, Universitas Gajahmada. Yogyakarta

[22] Parthasarathi, P., D. Levinson. (2010). Post-construction evaluation of traffic forecast accuracy. Transport Policy (2010), doi:10.1016/j. tranpol.2010.04.010

[23] Parthasarathi, P., D. Levinson, H. Hochmair. (2013). Network Structure and Travel Time Perception. PLOS ONE | www.plosone.org 3 October 2013, Volume 8, Issue $10 \mid$ e 77718

[24] PosKota News. (2012). Wacana Pemekaran Kabupaten Bogor Barat Kembali Mengemuka. Retrieved from http://poskotanews.com/2012/06/21/ wacana-pemekaran-kabupaten-bogor-barat-kembalimengemuka/

[25] Rosenberg, M. (2018). Defining Accessibility and Mobility in Transportation and Geography. Retrieved from https://www.thoughtco.com/access ibilitydefinition-geography-1434629.

[26] Salonen, M. and T. Toivonen. (2013). Modelling Travel Time in Urban Networks: Comparable Measures for Private Car and Public Transport. Journal of Transport Geography 31 (2013) 143-153

[27] Sander H. A., D. Ghosh, D. van Riper, S. M. Manson. (2010). How do you measure distance in spatial models? An Example Using Open-Space Valuation. Environment and Planning B: Planning and Design 2010, volume 37: $874-894$.

[28] Siyongwana, P.Q. (2012). The Selection of the Capital City of the Eastern Cape Province. HAL archivesouvertes. Retrieved from https://halshs.archivesouvertes.fr/halshs -00766816

[29] Silalahi S. L. Br., P. W. Handayani, Q. Munajat. (2017). Service Quality Analysis for Online Transportation Services: Case Study of GO-JEK. Procedia Computer Science 124 (2017): 487-495

[30] Song C, Guan W, Ma J. (2018). Potential Travel Cost Saving in Urban Public-transport Networks using Smartphone Guidance. PLOS ONE 13(5): e0197181. https://doi.org/10.1371/journal.pone.0197181

[31] Turner, S, W. Eisele, R. Benz, and D. Holdener. (1998). Travel Time Data Collection Handbook. Texas Transportation Institute, U.S. Department of Transportation

[32] Tifanny. (2017). Tarif Ojek Online: Murahan Go-Jek, Grab atau Uber Ya? Retrieved from https://www.moneys mart.id/tarif-ojek-online-go-jekgrab-uber/

[33] Wallsten S. (2015). The Competitive Effects of the Sharing Economy: How is Uber Changing Taxis? Retrieved from https://www.researchgate.net/ publication/279514652

[34] Wang F. dan Y. Xu. (2011). Estimating O-D Travel Time Matrix by Google Maps API: implementation, advantages, and implications. Annals of GIS Vol. 17, No. 4, December 2011: 199-209

[35] Winn, M. T. (2014). A Road Network Shortest Path Analysis: Applying Time-Varying Travel-Time Costs for Emergency Response Vehicle Routing, Davis County, Utah. Thesis. The Department of Humanities and Social Sciences, Northwest Missouri State University Maryville. Mis souri

[36] Yook D. dan K. Heaslip. (2015). Effective Modeling for a Distance-Based Fare Structure with a TimeExpanded Network. Journalof Public Transportation, Vol. 18, No. 1, 2015.

[37] ZevRoss Spatial Analysis. (2014). Google directions vs ESRI's Network Analyst: Estimates of time and distance. Retrieved from https://www.zevross.com/ blog/2014/07/23/google-directions-vs-esris-networkanalyst-estimates-of-time-and-distance/ 